\title{
Cash-Flow Sensitivities and the Allocation of Internal Cash Flow
}

\section{Xin Chang}

Nanyang Technological University

\section{Sudipto Dasgupta}

Hong Kong University of Science and Technology

\section{George Wong}

Hong Kong Polytechnic University

\section{Jiaquan Yao}

WISE \& SOE, Xiamen University

\footnotetext{
For constructive comments and suggestions, we are grateful to an anonymous referee, Haiqiang Chen, Long Chen, David Denis (the editor), Bruce Grundy, and Michael Lemmon. We thank James Morley for sharing BeveridgeNelson decomposition codes used by Morley, Nelson, and Zivot (2003) and Toni Whited for sharing her Stata codes for the GMM estimation used by Erickson and Whited (2012). Chang acknowledges financial support from Rega Capital Management Limited and Academic Research Fund Tier 1 provided by Ministry of Education (Singapore) (grant numbers SUG FY08 and M58010006). Wong acknowledges financial support from RGC Fund and Central Research Grant provided by the Hong Kong Polytechnic University (grant numbers A-PJ98 and G-YN61, respectively). Send correspondence to Sudipto Dasgupta, Department of Finance, Hong Kong University of Science and Technology, Clear Water Bay, Kowloon, Hong Kong; telephone: 852-2358-7685; fax: 852-2358-1749. E-mail: dasgupta@ust.hk.
} 


\title{
Cash-Flow Sensitivities and the Allocation of Internal Cash Flow
}

\begin{abstract}
We study how firms allocate cash flow by estimating the cash-flow sensitivities of various uses of cash flow. We decompose cash flow into a transitory and a permanent component and focus on the allocation of the transitory component, which by construction contains little information about future growth opportunities. We find that more financially constrained firms allocate more transitory cash flow to cash savings and direct less toward investment than do less constrained firms, consistent with constrained firms accumulating liquidity to buffer against future financial constraints. We also illustrate several methodological advantages of our approach over alternative methods in previous studies. (JEL G31, G32)
\end{abstract}


How do firms allocate internally generated cash among its various uses? The answer to this question is important for several reasons. Firms could pay out additional cash flow as dividends, use cash to reduce debt or equity financing, hold cash as precautionary savings, or spend the additional cash flow on investment. How firms use internally generated cash could affect the speed with which an economy recovers from a recession, which is typically accompanied by improvements in profitability.

The allocation of cash flow could also provide important insights into the types of frictions firms face in financing investment and how firms mitigate the constraints imposed by these frictions. There is very little theoretical guidance on how the degree of financial constraints is supposed to affect the allocation of cash flow. For example, theory does not provide a clear answer to the question of whether firms facing more severe financial constraints should invest more or save more when they have additional cash flow. ${ }^{1}$ Given this, there is a need for empirical evidence to inform theory. However, as we discuss below, it has been difficult to interpret available empirical evidence because existing empirical approaches face several challenges. One of the main contributions of this paper to provide a methodology that addresses some of these challenges and informs theory as to how firms facing different degrees of financial constraints allocate cash flow to various uses.

We measure the allocation of cash flow using the coefficients of cash flow in a regression framework in which various uses of cash flow are regressed on cash flow and other controls. The cash-flow sensitivity of a particular use of cash flow reveals how much of an additional dollar of cash flow is directed toward that use. ${ }^{2}$ To offer a complete view of the cash-flow allocation, we

\footnotetext{
${ }^{1}$ For instance, Kaplan and Zingales (1997) show that even in a one-period model, investment-cash flow sensitivities do not necessarily increase with the degree of financing constraints.

${ }^{2}$ The cash-flow sensitivities of investment and the change in cash holdings have been extensively studied in the literature. However, the estimates of cash-flow sensitivities have proven to be controversial. See, among others,
} 
simultaneously track all cash flow uses, which are interrelated by the identity that the sum of all uses of cash flow must equal cash flow itself. In our integrated regression framework, this cashflow identity implies that the cash-flow sensitivities of various uses of cash flow must add to unity, which is hereafter referred to as the "adding-up constraint". In other words, because all cash flow uses must completely absorb a cash-flow shock, if cash flow increases by one dollar, the incremental allocations to all cash flow uses must sum to one dollar.

For a large panel of U.S. firms from 1971 to 2011, we define cash flow and its uses using the flow-of-funds (cash flow) statement from Compustat, so that the cash-flow identity holds well in our data. We then use ordinary least squares (OLS) regressions to separately estimate five equations that describe firms' five uses of cash flow, that is, investment, the change in cash holdings, dividends, net equity repurchases, and net debt reductions. ${ }^{3}$ The results show that the coefficients of cash flow across five equations add to one.

Although the adding-up constraint holds under OLS estimation, a common critique of interpreting cash-flow coefficients in the OLS regression framework is that cash flow may contain information about a firm's future prospects if future growth opportunities are not properly controlled for. To address this issue, we employ the approach of Beveridge and Nelson (1981; BN hereafter) to decompose cash flow into a trend (permanent) and a cycle (transitory) component. ${ }^{4} \mathrm{BN}$ show that the cycle measure contains little information about the future beyond short-term momentum. While the coefficients of both components of cash flow satisfy the

Fazzari, Hubbard, and Petersen (1988), Kaplan and Zingales (1997), Cleary (1999), Erickson and Whited (2000), Almeida, Campello, and Weisbach (2004), and Riddick and Whited (2009). In particular, given the diversity of methodologies and results on cash-flow sensitivities of these specific uses of cash flow, it is perhaps fair to say that there is no clear consensus as to where an additional dollar of cash flow goes.

${ }^{3}$ We do not consider the change in working capital as a use of cash flow. Instead, we include it in the calculation of cash flow, as suggested by Bushman, Smith, and Zhang (2011). The rationale is detailed in Section 2.2.

${ }^{4}$ Beveridge and Nelson's decomposition is widely used in the asset pricing literature, such as by Cochrane (1994), Bansal, Dittmar, and Kiku (2009), Garleanu, Kogan, and Panageas (2012) and Garleanu, Panageas, and Yu (2012). However, its use in the corporate finance literature is rather limited. 
adding-up constraint under OLS, only those for the cycle component can be reliably interpreted as estimates of the use of cash flow. This is because whereas the trend component of cash flow contains information about future cash flow growth and thus is likely to correlate with the error terms when growth opportunities are inadequately controlled for, this is less likely for the cycle component. Therefore, to the extent that the cycle component is uncorrelated with future growth opportunities, the coefficient of this component is consistently estimated and can be meaningfully interpreted.

We incorporate both cash flow components into our integrated regression model to examine how firms allocate these respective cash flow components. Economically, in response to a one-dollar increase in transitory cash flow, on average, firms allocate 23 cents to investment, 36 cents to cash holdings, 1 cent to dividends, 32 cents to debt retirements, and 9 cents to equity reductions. Consistent with the information content of cash flow components discussed above, we find that investment responds much more positively to the trend component of cash flow than to the cycle component.

To explore how the degree of financing frictions (or financial constraints) affects the allocation of cash flow, we partition our sample using a variety of financial constraints measures used in the literature and then estimate the allocation of transitory cash flow for financially more constrained and less constrained firms separately. The results reveal that in response to an additional dollar of transitory shock to cash flow, less financially constrained firms, which are typically larger and have better access to external capital markets, reduce new equity financing by 3 to 4 cents, depending on the financial constraints measures used. However, this magnitude increases to 9 to 12 cents for more financially constrained firms. Moreover, regardless of which criteria is being used to distinguish between financially more and less constrained firms, the 
former group exhibits a lower investment-cash flow sensitivity and a higher cash holding-cash flow sensitivity than the latter group.

The finding that more financially constrained firms allocate less cash flow to investment than their less constrained counterparts may appear surprising because the literature has usually assumed that more constrained firms should rely more on internal cash flow for investment given their restricted access to capital markets. ${ }^{5}$ However, we conjecture that this result highlights the importance of the interdependent nature of various uses of cash flow through the cash flow identity. To wit, as firms become more financially constrained, they should be more willing to reduce the use of costly external finance with internal cash flow. In the meantime, they may face tighter financial constraints not only in the present but also in the future. Therefore, they may use cash flow to reduce the current use of external finance or save more cash out of cash flow to accumulate liquidity as a buffer against future constraints (e.g., Hubbard 1998; Dasgupta and Sengupta 2007). Because reducing external finance, addition to cash holdings, and investment are competing uses of cash flow (which are interdependent through the cash flow identity), if more constrained firms direct a larger portion of each additional dollar of cash flow to cash reserves and reducing external finance, then a smaller portion is left for investment.

We then conduct additional analysis to ensure that our main results are robust to alternative model specifications. Furthermore, we perform two tests to compare our methodologies with those used in previous studies. First, Gatchev, Pulvino, and Tarhan (2010; GPT hereafter) propose that the cash-flow sensitivities should be estimated using a constrained system of equations with the adding-up constraint imposed explicitly. They show that estimating all the cash-flow sensitivities simultaneously without explicitly imposing the constraint leads to

\footnotetext{
${ }^{5}$ Two exceptions are Kaplan and Zingales (1997) and Cleary (1999), who also document that financially constrained firms exhibit a lower investment-cash flow sensitivity than do unconstrained ones.
} 
erroneous coefficient estimates. GPT's claim, however, is false. Using our sample, we estimate the cash-flow sensitivities with the adding-up constraint imposed and without. Unlike GPT, however, we find that explicitly imposing the constraint makes no difference to our estimates. The reason is simple: when variables are consistently defined and satisfy the cash-flow identity in the data, the estimated cash flow coefficients should meet the adding-up constraint automatically, thereby making the constraint redundant in the estimation. We further show that GPT's findings are due to inconsistent variable definitions, which violate the cash-flow identity for a substantially large percentage of observations in their sample.

Second, Erickson and Whited $(2000,2002)$ show that the measurement errors associated with Tobin's marginal q, which is supposed to capture investment opportunities, can have serious consequences on inference based on the cash-flow coefficients. They propose a modified generalized method of moments (GMM) method based on higher-order moments to correct for the measurement errors. ${ }^{6}$ We estimate our five equations separately using the GMM estimators proposed by Erickson and Whited (2000; 2002). Although theory does not pin down the exact value for the expected cash-flow coefficient in each equation, to the extent that GMM estimators offer consistent estimates for all equations, the cash flow coefficients should add to unity across five equations. However, our results show that unlike OLS estimates that always satisfy the adding-up constraint, GMM estimates violate the constraint often by large amounts. The upshot of this comparison is that when applied to real data, the GMM estimators fail to offer economically meaningful estimates of the cash-flow allocation across various uses.

Our paper makes several contributions, both in terms of the estimates of the cash-flow allocation and empirical methodology. In terms of the allocation of cash flow among competing

\footnotetext{
${ }^{6}$ This methodology has been profoundly influential in the subsequent literature that examines the cash-flow sensitivities of investment or cash holdings. See, among others, Whited (2001, 2006), Hennessey (2004), Colak and Whited (2007), and Riddick and Whited (2009).
} 
uses, we document that substitution of external financing is the most important single use of transitory cash flow and that financially more constrained firms allocate more out of an additional dollar of transitory cash flow to cash holdings but less to investment than less constrained firms. In terms of methodology, we suggest an alternative way to address the measurement error problem that makes interpretation of cash flow coefficients problematic in an OLS setting, by focusing on a component of cash flow that is orthogonal to future growth opportunities. This is necessitated because, as we demonstrate, it is problematic to interpret coefficient estimates based on available higher-order moment methods applied to individual equations because the adding-up constraint can be easily violated. By establishing that the OLS method has the virtue that the adding-up constraint is always satisfied, we suggest a way in which the allocation of the transitory component of cash flow can be meaningfully studied without the information content of cash flow affecting our inference. ${ }^{7}$

\section{Empirical Methodologies}

\subsection{Regression equations}

Our empirical analysis critically hinges upon the following cash-flow identity defined using flow-of-funds data:

$$
\operatorname{Inv} v_{t}+\Delta \operatorname{Cash}_{t}+\operatorname{Div}_{t}-\Delta D_{t}-\Delta E_{t}=C F_{t}
$$

where the uses of funds include investment (Inv), the change in cash holdings $(\triangle C a s h)$, and cash dividends (Div). The sources of funds comprise the internally generated cash flow $(C F)$ and

\footnotetext{
${ }^{7}$ In a related study, Gorbenko and Strebulaev (2010) theoretically examine firm financial policies in the presence of both transitory and permanent shocks to cash flow and emphasize the role of transitory shocks, which are neglected by prior capital structure studies. However, they do not empirically decompose cash flow into transitory and permanent components. Moreover, they mainly examine the effect of transitory shocks on financing decisions, instead of on investment and cash savings decisions.
} 
external financing that consists of the net debt issuance $(\Delta D)$ and the net equity issuance $(\Delta E)$. $\Delta D$ and $-\Delta E$ represent net reductions in external financing, which are regarded as uses of funds.

Our baseline empirical models regress different uses of cash (e.g., investment, the change in cash holdings, cash dividends, and net reductions in external financing) on $C F$, the market-tobook ratio $(M B)$ as a proxy for investment opportunities, and control variables $(Y)$. We also include firm dummies $(f)$ to control for unobserved heterogeneity and year dummies $(y)$ to account for time effects. The regression equations are written as follows:

$$
\begin{gathered}
I n v_{i t}=\alpha^{I n v} C F_{i t}+\beta^{I n v} M B_{i t-1}+\gamma^{I n v} Y_{i t-1}+f_{i}+y_{t}+\varepsilon_{i t}^{I n v}, \\
\Delta C a s h_{i t}=\alpha^{\Delta C a s h} C F_{i t}+\beta^{\Delta C a s h} M B_{i t-1}+\gamma^{\Delta C a s h} Y_{i t-1}+f_{i}+y_{t}+\varepsilon_{i t}^{\Delta C a s h}, \\
D i v_{i t}=\alpha^{D i v} C F_{i t}+\beta^{D i v} M B_{i t-1}+\gamma^{D i v} Y_{i t-1}+f_{i}+y_{t}+\varepsilon_{i t}^{D i v}, \\
\Delta D_{i t}=\alpha^{\Delta D} C F_{i t}+\beta^{\Delta D} M B_{i t-1}+\gamma^{\Delta D} Y_{i t-1}+f_{i}+y_{t}+\varepsilon_{i t}^{\Delta D}, \\
\Delta E_{i t}=\alpha^{\Delta E} C F_{i t}+\beta^{\Delta E} M B_{i t-1}+\gamma^{\Delta E} Y_{i t-1}+f_{i}+y_{t}+\varepsilon_{i t}^{\Delta E} .
\end{gathered}
$$

The allocation of cash flow across various uses is captured by the coefficients of $C F$ in Equations (2)-(6). Because investment, cash holdings, dividend, and financing decisions are made jointly, subject to Equation (1) that cash flow must equal uses of cash flow, the cash-flow sensitivities of various uses of cash flow must add to unity. Mathematically, the coefficient estimates in Equations (2)-(6) must satisfy the following conditions.

$$
\begin{aligned}
& \alpha^{I n v}+\alpha^{\Delta C a s h}+\alpha^{D i v}-\alpha^{\Delta D}-\alpha^{\Delta E}=1, \\
& \beta^{I n v}+\beta^{\Delta C a s h}+\beta^{D i v}-\beta^{\Delta D}-\beta^{\Delta E}=0, \\
& \gamma^{I n v}+\gamma^{\Delta C a s h}+\gamma^{D i v}-\gamma^{\Delta D}-\gamma^{\Delta E}=0 .
\end{aligned}
$$

The adding-up constraint (7) reflects the accounting identity that sources of cash equal uses of cash. In other words, a one-dollar increase in internal cash flow needs to be used to increase 
investment, increase cash holdings, pay cash dividends, or reduce outstanding debt or equity. Constraints (8) and (9) stipulate that the total response across different sources and uses of funds must sum to zero if the shock stems from an exogenous or predetermined variable that represents neither a source nor a use of funds in the current period. ${ }^{8}$

If the variables in Equation (1) are consistently defined so that the cash-flow identity holds implicitly in the data, constraints (7)-(9) should hold automatically and need not be imposed explicitly in the estimation. Furthermore, Equations (2)-(6) can be estimated simultaneously using seemingly unrelated regressions (SUR), because each equation in the system has its own dependent variable and the explanatory variables in all equations are either exogenous or predetermined. Greene (2012) suggests that SUR estimates are equivalent to equation-byequation OLS estimates if the same set of explanatory variables is included in each equation, which is precisely the case in Equations (2)-(6). ${ }^{9}$ Taken together, we thus estimate Equations (2)-(6) separately using OLS regressions without imposing constraints (7)-(9) explicitly. In Section 4.1, we confirm that our unconstrained single-equation estimation generates the same results as those obtained by estimating Equations (2)-(6) simultaneously using the SUR method with constraints (7)-(9) imposed.

For control variables $(Y)$, we include the log of the book value of assets, $L n($ Assets), as a proxy for firm size. The sales growth (SalesG) is incorporated as an additional control for firm growth prospects. The net PPE-to-asset ratio (Tangibility) is used to measure the tangibility of firm assets. We also include the leverage ratio (Leverage) defined as total debt (the sum of shortterm and long-term debt) divided by total assets.

\footnotetext{
${ }^{8}$ For instance, suppose the coefficient of $M B$ is 0.1 in Equation (2), suggesting that investment increases by $10 \%$ of total assets if $M B$ increases by one. Because investment is a use of funds and total uses of funds must be equal to the total sources of funds, the net effect of the increase of $M B$ on other use variables must sum to $-10 \%$ of total assets.

${ }^{9}$ A detailed proof is included in the Internet Appendix of this article (IA.1). See also Greene (2012, 293-95).
} 


\subsection{Beveridge-Nelson decomposition of cash flow}

$\mathrm{BN}$ develop a procedure to decompose a univariate time series into trend (permanent) and cycle (transitory) components. The BN trend is defined as the limiting forecast of the level of the series (minus any deterministic drift), and the BN cycle is the difference between the level of the series and the trend component. Specifically, assume a univariate time series $y_{t}$, which is an I(1) (integrated of order 1) process with Wold representation as follows.

$$
\Delta y_{t}=\mu+\psi(L) \varepsilon_{t}=\mu+\sum_{j=0}^{\infty} \psi_{j} \varepsilon_{t-j}
$$

where $L$ is the lag operator, $\psi(L)$ is the lag polynomial, $\mu$ is the mean value of $\Delta y_{t}, \Delta$ is the first difference, that is, $\Delta=1-L, \psi(0)=1, \psi(1) \neq 0, \sum_{j=0}^{\infty} j^{1 / 2}\left|\psi_{j}\right|<\infty$, and $\varepsilon_{t} \sim$ i.i.d. $N\left(0, \sigma^{2}\right)$.

The trend component $\tau_{t}$ is defined as the limiting forecast of the level of the series (adjusted for the mean growth rate) or, equivalently, the current level of the series plus the infinite sum of the expected $j$-period-ahead change in $y$ :

$$
\tau_{t}=\lim _{J \rightarrow \infty} E_{t}\left[y_{t+J}-J . \mu\right]=y_{t}+\lim _{J \rightarrow \infty} \sum_{j=1}^{J} E_{t}\left[\left(\Delta y_{t+j}-\mu\right)\right]
$$

We then can have

$$
\tau_{t}-\tau_{t-1}=\lim _{J \rightarrow \infty}\left[E_{t}\left(y_{t+J}\right)-E_{t-1}\left(y_{t+J}\right)+\mu\right]
$$

$E_{t}\left(y_{t+J}\right)-E_{t-1}\left(y_{t+J}\right)$ can be viewed as the response of $y_{t+J}$ to the shock at $t$. Because $E_{t}\left(y_{t+J}\right)-E_{t-1}\left(y_{t+J}\right)=\sum_{j=1}^{J} \psi_{j} \varepsilon_{t}$ and $\lim _{J \rightarrow \infty}\left[E_{t}\left(y_{t+J}\right)-E_{t-1}\left(y_{t+J}\right)\right]=\psi(1) \varepsilon_{t}$, we can write

$$
\tau_{t}-\tau_{t-1}=\mu+\psi(1) \varepsilon_{t}
$$


Hence, the $\mathrm{BN}$ trend is a pure random walk with drift $\mu$ and its innovation variance is $\sigma^{2} \psi(1)^{2}$. The BN cycle, $c_{t}$, is the difference between the present level of the series $\left(y_{t}\right)$ and the trend component $\left(\tau_{t}\right)$ :

$$
c_{t}=y_{t}-\tau_{t}=\tilde{\psi}(L) \varepsilon_{t},
$$

where $\tilde{\psi}(L)=\sum_{j=0}^{\infty} \tilde{\psi}_{j} L^{j}$ and $\tilde{\psi}_{j}=-\sum_{k=j+1}^{\infty} \psi_{k}$.

Essentially, the derivation above suggests that the trend component is a random walk with drift and the cycle component is a stationary process with zero mean. Empirically, we follow the methodology of Morley, Nelson, and Zivot (2003) and perform the BN decomposition by fitting the first difference of unscaled cash-flow series with an $A R M A(2,2)$ model. The decomposition is detailed in Appendix A. After obtaining the trend and cycle components of unscaled cash flow, we deflate both components by the beginning-of-period book value of assets to get $\mathrm{CF}_{-}$Trend and CF_Cycle. 


\section{Data and Variables}

\subsection{Data}

Our sample consists of firms listed in the Compustat Industrial Annual files at any point between 1971 and 2011. We follow Frank and Goyal (2003) and use the flow-of-funds data to define variables in the cash-flow identity. We set the starting point of our sample at 1971, because this is the year that Compustat starts to report flow-of-funds data extensively. Data on stock prices and returns are retrieved from the Center for Research on Security Prices (CRSP) files. Dollar values are converted into 2000 constant dollars using the GDP deflator.

Following common practice, we discard observations from financial institutions (SIC codes 6000-6999), utilities (SIC codes 4900 4999), not-for-profit organizations, and government enterprises (SIC codes greater than 8000). ${ }^{10}$ We require firms to provide valid information on their total assets, sales growth, market capitalization, changes in cash holdings, investment, cash dividends, cash flow, and external financing. Following Almeida, Campello, and Weisbach (2004) and Almeida and Campello (2010), we exclude firm-years for which the market value of assets is less than $\$ 1$ million, those displaying asset growth exceeding $100 \%$, and those with annual sales lower than $\$ 1$ million to minimize the sampling of financially distressed firms. ${ }^{11}$ Furthermore, to ensure that the cash-flow identity holds well in our data, we exclude observations for which the absolute value of the difference between the left-hand and right-hand sides of Equation (1) is greater than $1 \%$ of the beginning-of-period total assets. ${ }^{12}$ Finally, to

\footnotetext{
${ }^{10}$ Utility firms, not-for-profit organizations, and government enterprises are excluded because they are heavily regulated. We discard financial firms because their financing decisions are affected by different factors (e.g., capital adequacy regulations) that are almost irrelevant for nonfinancial firms.

${ }^{11}$ Very small firms (with the market value of assets or sales less than $\$ 1$ million) are removed because they have severely limited access to capital markets. Our results are essentially unchanged if we increase the cutoff for defining very small firms from $\$ 1$ million to $\$ 5$ million. Firms experiencing extremely high growth are eliminated because they are normally involved in major corporate events, such as mergers and acquisitions.

${ }^{12}$ A number of observations (396) are deleted from our main sample because of this treatment. In Section 2.3, we elaborate on various causes of violation of the cash-flow identity.
} 
ensure that the $\mathrm{BN}$ decomposition of cash flow can be performed with a reasonably long time series, we restrict the sample to firms with at least fifteen years of cash flow data in Compustat. ${ }^{13}$ These screens leave us with an unbalanced panel that consists of 46,991 firm-year observations.

\subsection{Variables in the cash-flow identity}

According to Compustat data manuals, it is important to consider the format code when defining variables using flow-of-funds data. Effective for fiscal years ending on July 15, 1988, Statement of Financial Accounting Standards (SFAS) \#95 requires U.S. companies to report the Statement of Cash Flows (format code $=7$ ). Prior to the adoption of SFAS \#95, companies may have reported one of the following statements: Working Capital Statement (format code $=1$ ), Cash Statement by Source and Use of Funds (format code = 2), or Cash Statement by Activity (format code $=3$ ). Thus, the variable definitions vary depending on which format code a firm follows in reporting flow-of-funds data. In particular, for investment we include capital expenditure, acquisitions paid by cash, and other investment that result in cash outflows. For issuance and repurchase activities, we consider those that are associated with actual cash inflows or outflows. Following Fama and French (2005), the issuance activities generating no cash flow to the firm, such as granting shares to employees or financing acquisitions with stock, are excluded from our analysis. Table 1 details the construction of all variables in Equation (1) based on different format codes of flow-of-funds data.

\footnotetext{
${ }^{13}$ Our results are qualitatively the same if we require the firms to have at least consecutive 10 or 20 years of cash flow. In addition, when estimating the ARMA model, the standard BN procedure utilizes the whole time series of a firm to decompose cash flow. In any given year $t$, cash flow is decomposed based on both historical information from year 1 (the first year the firm entering our sample) to year $t$ and future information from year $t+1$ to $N$ (the number of periods for which cash-flow data are available). As an additional analysis, which aims to show that our findings are not mainly due to the "look-ahead bias" created by the use of future information, we decompose $C F$ in year $t$ using realized data from year 1 to year $t$. Because the BN decomposition requires a reasonably long time series to estimate the ARMA model, we perform this analysis from year 10 onward (i.e., $t \geq 10$ ) for each firm. We then estimate the cash-flow sensitivities based on the BN decomposition using realized data and obtain results (untabulated) similar to those reported in Tables 3 and 4.
} 
[Insert Table 1 here]

It is worth noting that, following recent studies on cash-flow sensitivities (e.g., Bushman, Smith, and Zhang 2011; Dasgupta, Noe, and Wang 2011; GPT), we define cash flow (CF) as the operating cash flows, net of the change in working capital. ${ }^{14}$ Bushman, Smith, and Zhang (2011) suggest that the cash flow measure used almost universally in the investment-cash flow literature is essentially earnings before depreciation, which contains a true cash component (operating cash flows) and a noncash component in the form of working capital accruals. They find that the investment-cash flow sensitivity documented in previous studies is mainly due to the naturally positive correlation between investment and working capital accruals. ${ }^{15}$ By removing the effect of the change in working capital and focusing on cash flow from operations, we mitigate the concern that our results are driven by the correlations between the uses of funds (investment in particular) and working capital accruals.

\subsection{Summary statistics}

Table 2 reports summary statistics for the variables used in the regression analysis. All flow-of-funds variables are deflated by the beginning-of-period total assets and have been winsorized at the top and bottom $1 \%$ of their distributions. This approach reduces the impact of extreme observations by assigning the cutoff values to those that are beyond the cutoff points. Our results (untabulated) are qualitatively the same when we truncate (rather than winsorize) the distributions.

\footnotetext{
${ }^{14}$ For instance, for firms with format code $=7, C F$ is defined as income before extra items + extra items and discontinued operation + depreciation and amortization + deferred taxes + equity in net loss + gains in sale of PPE and investment + other funds from operation + exchange rate effect - change in working capital $(\triangle W C)$. The definitions of $C F$ for firms with other format codes are detailed in Table 1.

${ }^{15}$ Because fixed assets investments normally increase firm scale, it is natural to expect corresponding increases in noncash working capital items, such as accounts receivables and inventories. However, this relation has little to do with financing constraints caused by capital market imperfections but rather is a manifestation of increasing scale.
} 


\section{[Insert Table 2 here]}

On average, every year, our sample firms invest (Inv) 9.2\%, increase cash holdings ( $\triangle$ Cash) by $0.9 \%$, and pay out as dividends (Div) $1.1 \%$ of the beginning-of-period assets. To finance these uses of funds, an average firm in our sample taps external capital markets by issuing debt and equity that amounts to $1.4 \%$ and $1.6 \%$ of the beginning-of-period assets, respectively. The gap between the uses of funds and external financing is met by internally generated cash flow $(C F)$, which accounts for $8.3 \%$ of the beginning-of-period assets. Except for dividends (Div), all flowof-funds variables exhibit significant variation, ranging from large negative to large positive values.

As mentioned in Section 2.1, we have excluded observations with the absolute value of the difference between the left-hand and right-hand sides of Equation (1) greater than $1 \%$ of total assets. ${ }^{16}$ Thus, the cash-flow identity (Equation (1)) holds up well in our sample, albeit not perfectly. We define $D I F^{\text {Equation } 1}$ as the difference between the left-hand and right-hand sides of Equation (1), with all variables deflated by the beginning-of-period total assets. The mean, median, and standard deviation of $D I F^{\text {Equation } 1}$ are 0,0 , and 0.003 , respectively.

\footnotetext{
${ }^{16}$ There are mainly four causes resulting in a violation of the cash-flow identity: (1) defining variables using data from different sources (i.e., balance sheet, income statement, and cash flow statement), (2) misrecorded data for any variable in the cash-flow identity, (3) rounding errors, and (4) winsorization. As we show in Section 4.1, cause (1) leads to severe violation of the cash-flow identity for most firm-years. Cause (2) applies to a small number of firmyears only but may result in extreme values of $D I F^{\text {Equation } 1}$. Cause (3) contributes to violation of the cash-flow identity for many firm-years, but its magnitude and its effect on the estimated cash-flow sensitivities should be negligible. Finally, winsorization can also slightly perturb the cash-flow identity for a small number of firms because not all scaled variables in the cash-flow identity take extreme values simultaneously in a given firm-year. Because we define variables only using the cash-flow statement, cause (1) does not apply to our sample. To mitigate the effects of causes (2), (3), and (4), we drop 396 firm-years with $\left|D I F^{\text {Equation }}{ }^{1}\right|>1 \%$. Robustness checks (untabulated) show that our main results are unaffected if we make no modifications to the data, namely, if we do

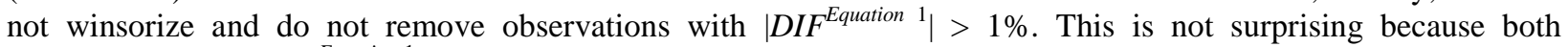
winsorization and $\left|D I F^{\text {Equation } 1}\right|>1 \%$ only affect a small number of firms. In addition, Compustat firms that report cash-flow statements completely normally have no highly extreme values for variables in the cash-flow identity.
} 


\subsection{The cycle and trend components of cash flow}

Table 2 also reports the summary statistics of the cycle and trend components of cash flow, which are obtained using BN's decomposition approach outlined in Section 1.2. The mean of the cycle component is close to zero, confirming its basic feature of a zero-mean stationary process. In contrast, the trend component has the mean of 0.084 , which is almost the same as the mean value of the level of cash flow. The correlation coefficient (untabulated) between the trend and cycle components, both scaled by lagged book value of assets, is -0.21 , which is significant at the $1 \%$ level. $^{17}$

The orthogonality of the cycle component with respect to growth opportunities is crucial for us to meaningfully interpret the cash-flow coefficients in the regressions. As discussed in Section 1.2, the logic of the BN decomposition suggests that the cycle component should reflect little else than short-term momentum, with the stochastic trend component capturing a persistent shock to future cash-flow growth. Here, we provide further evidence that the cycle component contains little information about future growth.

First, we decompose the market-to-book ratio into the cycle and trend components using the BN methodology and regard the latter component as a proxy for the long-term growth prospect. We find that the cycle component of cash flow is uncorrelated with the contemporaneous trend component of the market-to-book ratio (the correlation coefficient is 0.01 and the $p$ value is 0.43 ). This correlation supports the notion that the cycle component of cash flow contains little information about future growth prospects. In contrast, the trend component of cash flow is strongly correlated with the contemporaneous trend component of the market-to-

\footnotetext{
${ }^{17}$ The BN decomposition is not an orthogonal decomposition. Some other filters, such as the Hodrick-Prescott (1997) filter, generate orthogonal trend and cycle components. The relative merits of these alternative decompositions are controversial (e.g., Maravall 1995; Nelson 2008; Oh, Zivot, and Creal 2008). As a robustness check, we redo our tests using the Hodrick-Prescott filter and obtain very similar results (available upon request).
} 
book ratio (the correlation coefficient is 0.34 and significant at the $1 \%$ level). Second, we run a regression (untabulated) of the contemporaneous trend component of cash flow scaled by lagged assets on the past three lagged values of the cycle component of cash flow scaled by lagged assets and find that the $R^{2}$ is almost zero. Third, following Nelson (2008), we also regress the (unscaled) change in cash flow on the (unscaled) lagged cycle component. The co-efficient of the cycle component is negative, but the $R^{2}$ is $5 \%$, very comparable to that reported by Nelson (2008). This short-run predictability is expected because, as pointed out by Nelson (2008), if the series is below trend because the cycle component is negative, the recovery is expected to have an above-average future growth rate subsequently. However, when we regress the (unscaled) change in cash flow on the (unscaled) cycle component lagged two periods, the $R^{2}$ is almost zero. These findings are consistent with Nelson (2008), who documents that the cycle component contains little information about future growth beyond short-term momentum.

\section{Main Results}

\subsection{The allocation of cash flow across various uses}

Panel A of Table 3 reports the baseline results obtained by estimating Equations (2)-(6) as standalone equations. To estimate regressions with firm fixed effects, we demean the dependent and independent variables in Equations (2)-(6). ${ }^{18}$

[Insert Table 3 here]

In panel $\mathrm{A}$ of Table 3, we document positive investment-cash flow and cash-cash flow sensitivities and negative external finance-cash flow sensitivities. More specifically, a one-dollar

\footnotetext{
${ }^{18}$ Alternatively, we estimate the regressions by including firm dummies. Not surprisingly, the resulting coefficients are identical to those obtained by demeaning the variables. However, the estimation with firm dummies generally has a higher $R$-squared value than the demeaning approach, because the former explains the level of the dependent variable, whereas the latter explains the deviation of the dependent variables from their firm-specific means. We report the demeaning approach in order to facilitate the comparison with GPT's approach in Section 4.1.
} 
increase in cash flow increases investment by 28 cents, increases cash holdings by 33 cents, increases dividends by 1 cent, reduces the use of debt by 28 cents, and reduces the use of equity by 10 cents. To summarize, in response to a one-dollar increase in cash flow, the firms in our sample, on average, increase the uses of cash by roughly 60 cents and reduce reliance on external finance by roughly 40 cents.

In addition, we find that in Panel A of Table 3, $\alpha^{I n v}+\alpha^{\Delta C a s h}+\alpha^{D i v}-\alpha^{\Delta D}-\alpha^{\Delta E}=1$. For the coefficients of other explanatory variables, we have $\beta^{I n v}+\beta^{\triangle C a s h}+\beta^{D i v}-\beta^{\Delta D}-\beta^{\Delta E}=0$ and $\gamma^{I n v}+\gamma$ ${ }^{\Delta C a s h}+\gamma^{D i v}-\gamma^{\Delta D}-\gamma^{\Delta E}=0$. These findings indicate that although we estimate Equations (2)-(6) separately, constraints (7)-(9) hold automatically because the dependent variables are linked implicitly through the cash-flow identity (Equation (1)), which holds in our data, by definition.

While the OLS coefficients satisfy the aggregate constraints, their interpretation is still subject to the critique that cash flow contain information about future growth prospects. To mitigate this concern, we follow the approach outlined in Section 1.2 to decompose cash flow into a trend (permanent) and a cycle (transitory) component and focus on the cycle component, which should be less subject to this critique. The results are reported in Panel B of Table 3.

We first notice that for both the cycle and trend components, the adding-up constraint is satisfied - the sum of the coefficients for each component across the various uses is very close to unity (recall that the signs of the cash flow coefficients for debt and equity issuance columns need to be flipped). Next, consistent with the argument that cash flow contains information about future growth, and that the trend component is much more subject to this concern than the cycle component, in Column (6), we find that the coefficient of the trend component (0.34) in the investment equation is $50 \%$ higher than that of the cycle component (0.23). Finally, focusing on the coefficients of the cycle component, we find that an additional dollar of transitory shock to 
cash flow reduces external financing by about 41 cents and boosts the cash buffer by 36 cents. While the investment response is much lower ( 23 cents), it is still far from negligible. ${ }^{19}$

\subsection{Financial constraints and the allocation of cash flow}

How do financial constraints faced by firms affect their allocation of cash flow across various uses? Theoretically, we do not have a clear answer to this question, because existing models do not deliver clear predictions regarding whether firms facing more financing frictions should exhibit higher or lower cash flow sensitivity of investment than those facing less friction. ${ }^{20}$ There is almost no theory in this regard addressing the allocation of cash flow among its various uses.

Because theory either does not exist or has no clear predictions, one would hope that empirical results would inform theory. However, for reasons discussed earlier, it has proved difficult to interpret the cash flow coefficients corresponding to various uses of cash. Thus, we proceed to document how firms facing different degrees of financial constraints allocate cash flow, using our cash flow components and a variety of classification schemes used in the literature.

Specifically, we use classification schemes based on firm size (Ln(Assets)), the dividend payer dummy, credit ratings (e.g., Almeida, Campello, and Weisbach 2004), and more recent classifications suggested by Whited and Wu (2006; henceforth the $W W$ index) and by Hadlock

\footnotetext{
${ }^{19}$ Much of the investment-cash flow sensitivity literature has focused on capital expenditure rather than on total investment (as defined in Table 1, the latter includes capital expenditure, acquisitions paid in cash, and other longterm investment). As an additional analysis (untabulated), we separate capital expenditure from other forms of investment and find that the coefficient of the trend component is twice as large for capital expenditure than that of the cycle component. However, consistent with several studies (e.g., Almeida and Campello 2007), we find that a dollar of additional cycle component of cash flow increases capital expenditure by only 5 cents.

${ }^{20}$ See, for example, the debate between Fazzari, Hubbard, and Petersen (2000) and Kaplan and Zingales (2000).
} 
and Pierce (2010; henceforth the $H P$ index $).{ }^{21}$ By construction, higher scores of the $H P$ and $W W$ indexes indicate that firms are more financially constrained. Each year, a firm is classified as more (less) financially constrained if its Ln(Assets) is in the bottom (top) three deciles of the distribution, it pays zero (nonzero) dividends, its $H P$ index or $W W$ index is in the top (bottom) three deciles of the distribution, or if it does not have (has) a credit rating. We then estimate Equations (2)-(6) for financially more constrained and less constrained firms, respectively, and tabulate the results in Table 4. While all control variables in Table 3 are still included in the new tests, we only report the coefficients of $C F$ (panel A) and two $C F$ components (panel B) for brevity.

[Insert Table 4 here]

We focus on the coefficients of $C F \_C y c l e$, which is less likely to be influenced by future growth opportunities than are $C F$ and $C F \_$Trend. Panel B of Table 4 reveals that the coefficient of the cycle component in the investment regression is lower, and that in the cash holding regression is higher, for firms that are classified as more financially constrained, than those for firms classified as less constrained. In other words, more financially constrained firms allocate more (less) additional cash flow towards cash holdings (investment) than less constrained firms. ${ }^{22}$ There is no consistently significant difference in the total amount of external financing

\footnotetext{
${ }^{21}$ The $W W$ index is equal to $-0.091 \times C F /$ Assets $-0.062 \times$ Dividend Payer $+0.021 \times$ long-term debt/Assets $-0.044 \times$ Ln $($ Assets $)+0.102 \times$ industry median SaleG $-0.035 \times$ SaleG. The HP index is defined as $-0.737 \times$ Ln $($ Assets $)+$ $0.043 \times$ Ln $(\text { Assets })^{2}+0.04 \times$ Firm Age. Firm Age is the number of years elapsed since a firm enters the CRSP database. We find qualitatively similar results using the alternative classifications suggested by Kaplan and Zingales (1997) and Cleary (1999). The only exception is that firms classified as more constrained using Kaplan and Zingales' (1997) index exhibit no significant difference in the investment response to $C F \_C y c l e$ relative to their less constrained counterparts. We do not tabulate these results because Hadlock and Pierce (2010) show that in various contexts, Kaplan and Zingales' (1997) index is a less reasonable measure of financial constraints than the HP index.

${ }^{22}$ The differences in the Inv-CF_Cycle sensitivity between more and less constrained firms are statistically significant at conventional levels, except for the dividend payout classification scheme. Similar results are obtained when we measure investment using capital expenditure only: the cash-flow sensitivity of capital expenditure with respect to the cycle component is consistently lower for more constrained firms than for less constrained firms. The coefficients for less constrained firms are between 0.07 and 0.11 , whereas those for more constrained firms are between 0.04 and 0.05 .
} 
that is substituted by additional cash flow for the two groups. However, a regularity consistently observed is that the more constrained firms substitute more (less) equity (debt) using additional cash flow than the less constrained ones. This is consistent with the possibility that more constrained firms, for example, smaller or younger firms, are likely to be more equity dependent.

We now briefly speculate on these results, leaving the modeling challenge to theory. Perhaps the most surprising aspect of these results is that the financially less constrained firms exhibit higher investment-cash flow sensitivities than do the more constrained firms. The literature has usually assumed that the firms that are classified as "more constrained" are less able to access capital markets and face more financing frictions. If so, they should be unable to readily undertake all positive net present value (NPV) projects, and we should expect their investment to respond more positively to cash flow that does not reflect growth opportunities. However, more constrained firms face tighter financial constraints not only in the present but also in the future. Thus, one explanation for our results is that by adding to cash holdings and reducing external financing at the expense of more investment today, more constrained firms allocate liquidity optimally over time and preserve their ability to invest in the future. ${ }^{23}$

An alternative explanation is that the less constrained firms overinvest: managers like projects, and financing is readily obtained for positive NPV projects. However, it may be difficult to convince investors to provide capital when projects do not have positive NPV, and these projects can only be financed with internal funds. Thus, higher cash flow leads to higher investment in pet projects, with some cash saved away for future pet projects. More constrained firms do not have enough funds to invest in all good projects anyway, so they do not overinvest today as the cash is valuable for future good projects.

\footnotetext{
${ }^{23}$ See Dasgupta and Sengupta (2007) for a model along these lines.
} 


\subsection{Additional analysis and robustness checks}

We conduct two additional tests to ensure that our main results are robust to alternative model specifications. ${ }^{24}$ While all control variables in Table 3 are still included in the new tests, we only report the coefficients of cash flow variables and the newly added variables for brevity. For the tests regarding the effects of financial constraints, we only tabulate the results obtained using the classification scheme based on firm size. Other classification schemes generate qualitatively similar results but are not reported to save space.

[Insert Table 5 here]

First, prior studies (e.g., Dasgupta, Noe, and Wang 2011) have shown that firms stage their investment response to cash flow shocks. For instance, a firm that experiences a positive cash flow shock may deploy excess cash flow to their cash reserves or reductions of external finance in the current period and then step up investment in subsequent periods by drawing down their cash holdings or raising more external capital. As a result, there could be a delay between the time cash flow is realized and the time the firm actually invest it. To account for the intertemporal allocation of cash flow, we augment Equations (2)-(6) by including two lags of the cash flow components. ${ }^{25}$ The estimated coefficients of the lagged cash flow components capture how the uses of cash flow today respond to an additional dollar of a cash flow component one and two years ago. The total response across different uses must sum to zero because the lagged cash flow components are predetermined variables.

The results reported in Panel A of Table 5 show that the lagged cash flow components are significantly associated with the current level of investment. For the whole sample, Inv $v_{t}$ increases by 4 cents $(0.03+0.01=0.04)$ and 5 cents $(0.05+0.00=0.05)$ in response to one-dollar increases

\footnotetext{
${ }^{24} \mathrm{We}$ thank the referee and the editor for suggesting the additional analysis.

${ }^{25}$ Similar results (untabulated) are obtained if we include three lags of the cash flow components. The estimated coefficients of cash flow components at $t-3$ are close to zero.
} 
in $C F_{-} C y c l e$ and $C F_{-} T r e n d$, respectively, in the previous two years. Moreover, $\Delta \operatorname{Cash}_{t}\left(\Delta D_{t}\right)$ reacts negatively (positively) to lagged cash flows, indicating that lagged cash flows increase $I n v_{t}$ indirectly through depleting cash balances and increasing debt issues at time $t$. Consistent with Dasgupta, Noe, and Wang (2011), we document that investment of less constrained firms is more responsive to lagged cash flow than that of more constrained firms. More importantly, compared with the findings reported in Tables 3 and 4, our results indicate that the inclusion of lagged cash flow components has no material impact on the estimated coefficients of $\mathrm{CF}_{-} \mathrm{Cycle}_{t}$ and CF_Trend .

Second, firms may exhibit asymmetric responses to cash-flow shocks in positive and negative cash-flow years. For example, Allayannis and Mozumdar (2004) argue that firms with negative cash flow are able to make only essential investments, so that any further cutback in investment in response to further declines in cash flow becomes infeasible. As a result, one should expect the investment-cash flow sensitivity to be low in negative cash flow years. To investigate possible asymmetry in the allocation of cash flow, we include in the regressions $N E G$, which is a dummy variable that equals one if $C F$ is negative and zero otherwise, and the interaction terms between $N E G$ and the two cash flow components. The results reported in panel B of Table 5 suggest that firms with negative cash flow display lower investment-cash flow and cash-cash flow sensitivities than those with positive cash flow. Moreover, firms with negative cash flow have stronger substitutions between internal cash flow and external finance (i.e., more negative external finance-cash flow sensitivities), indicating that they tap external markets more for capital in response to further declines in cash flow. Less (more) constrained firms with negative cash flow rely more on debt (equity) financing to substitute the use of internal funds. The coefficients of $C F \_C y c l e_{t}$ and $C F \_$Trend , $_{\text {, which }}$ capture the cash-flow sensitivities in 
positive cash flow years, confirm our main results that more constrained firms allocate more (less) transitory cash flow to cash savings (investment) than do less constrained firms, suggesting that our findings are not primarily driven by the inclusion of negative cash-flow observations in the sample.

\section{Comparisons with Methodologies Used in Prior Studies}

\subsection{Comparison with GPT}

Unlike our methodology that estimates Equations (2)-(6), which are implicitly linked through the cash-flow identity, as standalone equations, GPT argue that the equations should be estimated simultaneously with constraints (7)-(9) explicitly imposed. The authors show that forcing the constraints to hold leads to substantially different coefficient estimates than those obtained if the equations for various uses of cash flow are estimated separately. In this subsection, we compare our methodology with GPT's. To save space, we tabulate the results of the comparison in the Internet Appendix (IA.2) of this article.

GPT's analysis relies on a cash-flow identity similar to Equation (1). ${ }^{26}$ However, unlike our study that only uses cash flow statements to define variables in the cash-flow identity, GPT define variables using data from different sources. Specifically, they employ balance sheet data to define $\Delta$ Cash, the change in net working capital, net short-term debt issuances, and net long-

\footnotetext{
${ }^{26}$ Their identity is $\triangle$ Cash $_{t}+$ Div $_{t}+C A P X_{t}+A C Q U I S_{t}-A^{2} A L E S_{t}-(E Q I S S U-R P)_{t}-(\triangle L T D+\triangle S T D)_{t}=C F_{t}$, where CAPX is net capital expenditures, ACQUIS is acquisitions, ASALES is sale of assets and investment, EQISSU stands for equity issuances, $R P$ represents equity repurchases, $\triangle L T D$ is net long-term debt issuances, and $\triangle S T D$ is net shortterm debt issuances. Our Equation (1) is less detailed because several variables in Equation (1) consolidate some of the items in GPT's equation. In particular, our measure of investment (Inv) aggregates capital expenditure (CAPX), acquisition (ACQUIS), and the sales of investment (ASALES). Our measure of net debt issuance $(\triangle D)$ captures funds from both short-term $(\triangle S T D)$ and long-term debt $(\triangle L T D)$ financing. In addition, $\Delta E$ is equal to the difference between two items in GPT's equation, EQISSU and RP. Our purpose of consolidation is to simplify the empirical analysis and ease exposition. Untabulated robustness checks indicate that our results remain qualitatively the same if we use GPT's cash-flow identity instead of Equation (1), so long as all items are defined properly using cash-flow statements.
} 
term debt. They use income statement data to define cash flow and rely on cash flow statement data to define equity issuances and repurchases, investment items, and cash dividends (Table III of GPT, 737). As a result, their cash-flow identity generally does not hold in their data. The disturbance to GPT's cash-flow identity is further magnified by their treatment of missing values in defining variables. GPT replace all missing values of the variables in the cash-flow identity by zeros. This unusual treatment of missing values boosts their sample size but increasingly worsens the cash-flow inequality because not all components in the identity have missing values at the same time in a given firm-year.

We define variables in the cash-flow identity by closely following GPT's definitions and their way of treating missing values. We obtain 221,119 firm-years, a sample size quite close to theirs $\left(237,412\right.$ firm-years). We define $D I F^{G P T}$ as the difference between the left-hand and righthand sides of GPT's cash-flow identity, with all variables deflated by the beginning-of-period total assets. Summary statistics reveal that, although the mean and median values of $D I F^{G P T}$ are close to zero (0.013 and 0.001 , respectively), its distribution is widely dispersed, with a standard deviation equal to 0.396 . Additional statistics indicate that the sample contains roughly $76 \%$ (25\%) of observations with the absolute value of $D I F^{G P T}$ larger than $1 \%$ (10\%), confirming our conjecture that GPT's cash-flow identity is severely violated in their data.

We then use this large sample to estimate the cash-flow sensitivities of various uses of cash flow. Consistent with GPT, we document drastic changes in the estimated coefficients of cash flow when we move from unconstrained single-equation models to constrained system-ofequations models. To check whether the changes in coefficient estimates are caused by estimation methods or inconsistently defined variables, we re-estimate Equations (2)-(6) simultaneously using the SUR method with constraints (7)-(9) imposed for our sample for which 
cash-flow identity typically holds. Contrary to GPT, we find that the estimated coefficients $(\alpha, \beta$, and $\gamma$ ), $t$-statistics, and $R$-squared values are almost identical to those reported in panel A of Table $3{ }^{27}$ This result is consistent with Greene (2012), who shows that SUR estimates are equivalent to equation-by-equation OLS estimates if the same set of explanatory variables is included in each equation. More importantly, our findings suggest that it is the severely unbalanced cash-flow identity in GPT's data that drives the significant differences in the estimated cash-flow sensitivities between the unconstrained single-equation model and the constrained system-of-equations model.

GPT also argue that it is indispensable to take into account the intertemporal dependencies within and across various uses of cash flow by adding lagged dependent variables. ${ }^{28} \mathrm{We}$ thus augment Equations (2)-(6) by controlling for $I n v_{t-1}, \Delta \operatorname{Cash}_{t-1}, \operatorname{Div}_{t-1}, \Delta D_{t-1}$, and $\Delta E_{t-1}$. However, we find that the inclusion of lagged dependent variables has no material impact on the coefficient estimates of cash flow. Taken together, our analysis suggests that the importance of explicitly imposing adding-up constraints and including lagged dependent variables is hugely exaggerated by GPT's reliance on a severely unbalanced cash-flow identity in their data.

\subsection{Estimating the cash-flow allocation using GMM estimators}

A well-known critique on cash-flow sensitivities in an OLS regression framework is that estimated coefficients are inconsistent because of the measurement errors associated with Tobin's marginal q, which captures investment opportunities. Because the true marginal $q$ cannot be observed, most previous studies use the average $q$ as a proxy, which is computed as the

\footnotetext{
${ }^{27}$ The estimated coefficients and $t$-statistics are very similar but are not identical to those reported in panel A of Table 3 because the cash-flow identity (Equation (1)) does not hold perfectly in our data. Thus, imposing the linear constraints (7)-(9) explicitly can still make a minor difference.

${ }^{28}$ For example, the current investment of a company may be affected by investment made, the change in cash holdings, and debt or equity issued last year.
} 
market-to-book ratio $(M B)$. Erickson and Whited $(2000,2002)$ show that the attenuation bias associated with mismeasured $q$ affects the coefficient of the well-measured regressor, such as cash flow. Erickson and Whited $(2000,2002)$ propose a modified GMM methodology, which is based on higher-order moments, to address the measurement error in Tobin's q.

Appendix B derives the potential biases caused by the measurement errors and three different GMM estimators (GMM3, GMM4, and GMM5) proposed by Erickson and Whited (2000, 2002). These estimators are based on the third, fourth, and fifth moment conditions, respectively. GMM3 is exactly identified and its validity requires the rejection of the identification test. The validity of both GMM4 and GMM5 should be examined using overidentification tests because the number of moment equations involved is larger than that of unknown parameters. The GMM estimators are originally designed for cross-sectional data. To apply them to unbalanced panel structures, Erickson and Whited (2012) use a minimum distance estimator (MDE) to aggregate GMM estimates from different cross-sections. The final estimates are the weighted averages across the coefficients from different cross-sections with more accurate coefficients assigned with higher weights.

The usefulness and reliability of the GMM estimators has been debated. Almeida, Campello, and Galvao (2010) claim that fixed effects, error heteroskedasticity, or a low degree of data skewness can make the modified GMM methods generate inefficient and biased coefficients for both mismeasured and perfectly measured regressors. However, Erikson and Whited (2012) argue that Almeida, Campello, and Galvao (2010) conclusions stem from an inaccurate computation of the estimator. They propose using multiple starting values for the computation of GMM4 and GMM5, which requires numerical minimization of asymptotic variance functions. The usage of multiple different starting values ensures that GMM estimators 
correspond to the global, rather than a local minimum. The adoption of multiple starting values does not affect the performance of GMM3 because it is exactly identified.

So far, the debate has focused on the cash flow coefficient in the investment equation, rather than in a system-of-equations framework. If we estimate various equations separately and independently with GMM estimators using real data, it is difficult to judge whether GMM estimates are consistent because we do not know the true values of the cash flow coefficients in real data. ${ }^{29}$ However, in our integrated regression framework, if the GMM estimators are consistent, the coefficients of $M B$ should add to zero across different equations, and the coefficients of cash flow should add to unity across different equations. Thus, by looking at the sum of coefficients across different equations, we provide an alternatively way of evaluating the performance of the GMM approach using real data.

Each year we estimate Equations (2)-(6) using GMM3, GMM4, and GMM5. We use the minimum distance method to aggregate yearly coefficient estimates. To account for firm fixed effects, we apply the within transformation to the data. Following Erikson and Whited (2012), we report the results obtained using data both in the within-transformation form and level form. ${ }^{30}$

[Insert Table 6 here]

Panel A of Table 6 reports the GMM coefficients estimates of $C F$ and $M B$ for five equations using the within transformation form. The coefficients across five equations do not add to theoretical priors (one for $C F$ and zero for $M B$ ). Erikson and Whited (2012) suggest that choosing multiple starting values for the coefficients can avoid local optima and extreme

\footnotetext{
${ }^{29}$ Although Monte Carlo simulations may address the issue, the assumptions on which Monte Carlo simulations are based is likely to be inconsistent with what is the case in the real data.

${ }^{30}$ Within-transformation (transforming the observations for each firm into deviations from the firm-specific average) is a remedy for biases caused by the correlation between firm fixed effects and regressors. However, within transformation may cause the identification condition to be violated in the resulting model. Thus, Erickson and Whited (2000) use data in the level form.
} 
estimates. Using their codes, we experiment with 101 (-0.1 to 0.5 with a step of 0.006$)$ different starting values and obtain the estimates that minimize the objective functions. However, the results reveal that the sum of GMM4 or GMM5 coefficients of $M B$ is far away from zero. The sum of coefficients of $C F$ ranges between 0.79 and 0.86 for the three GMM estimators. ${ }^{31}$ In panel B of Table 6, we report the GMM coefficients obtained using data in the level form, from which we draw similar inferences. Overall, the GMM estimators cannot provide us with jointly consistent estimates as to how firms allocate cash flow across various uses.

\section{Conclusions}

We examine how firms allocate cash flow to corporate investment, cash holdings, dividends, and financing activities. We use the methodology of estimating the cash-flow sensitivities for the above uses of cash flow to determine how cash flow is allocated. When these cash-flow sensitivities are estimated in an OLS framework, the adding-up constraint that the cash-flow sensitivities across the various uses should add to unity is satisfied. However, one problem with the OLS approach is that it does not deal with the measurement error in Tobin's q, which potentially leads to inconsistent estimates of the cash flow coefficients. This makes the interpretation of the cash-flow sensitivities difficult.

We argue that one way to deal with the measurement error problem is to focus on the "transitory" component of cash flow that does not contain information about future growth. We show that the cycle component of cash flow obtained from a Beveridge-Nelson decomposition of

\footnotetext{
${ }^{31}$ We report the detailed yearly coefficient estimates for the investment regression (Equation (2)) in the Internet Appendix of this article (IA.3). Consistent with Almeida, Campello, and Galvao (2010), coefficients have extreme values in some years, suggesting that using multiple starting values fails to eliminate extreme estimates. In addition, some extreme estimates also have very small standard errors. Because the minimum distance algorithm assigns larger weights to the coefficients with small standard errors, extreme estimates with small standard errors dominate the final results. Furthermore, consistent with previous studies (e.g., Almeida and Campello 2007; Agca and Mozumda 2007), our sample passes both the identification and overidentification tests in only 10 out of 40 years.
} 
cash flow has several desirable properties toward this end. In addition, the coefficients of the cycle component satisfy the adding-up constraint. Thus, we provide a way in which the allocation of cash flow can be meaningfully studied in an OLS framework.

Our main findings are as follows. Firms allocate a substantial part of an additional dollar of transitory cash flow to reduce external financing, suggesting that the "deleveraging" incentive is strong when profitability improves. They also tend to add a significant part of the additional dollar of cash flow to their cash holding. Very little is paid out as dividends. The resulting impact on investment impact is small — to the extent of about 20 cents to a dollar of additional cash flow. A very robust pattern is that, the financially more constrained firms invest less, accumulate more in cash holdings, and substitute more equity capital than do the financially less constrained firms. This result is consistent with the idea that financially more constrained firms expect to face tighter financial constraints in the future, thereby saving more cash out of additional cash flow for precautionary motives and enhancing the ability to raise external capital in the future.

We show that our approach has methodological advantages over other approaches that have been proposed to deal with either the adding-up constraint or the measurement error problem. First, GPT show that imposing the adding-up constraint as a constraint and estimating the cashflow sensitivities simultaneously provides substantially different coefficients than those obtained when the equations are estimated independently. We show that the GPT claim is false, and their results are due to inconsistent data definitions that do not respect the cash-flow identity. To address the measurement error problem associated with OLS, higher-order GMM methods have been proposed, but their reliability have also been debated. We contribute to this literature by showing that the adding-constraint is violated by large amounts when these equations are estimated individually using the GMM estimators. In other words, when applied to real data, the 
GMM estimators fail to offer economically meaningful estimates of the cash flow allocation across various uses. 


\section{References}

Agca, S., and A. Mozumdar. 2007. Investment cash flow sensitivity: Fact or fiction? Working Paper, George Washington University.

Allayannis, G., and A. Mozumdar. 2004. The impact of negative cash flow and influential observations on investment-cash flow sensitivity estimates. Journal of Banking and Finance 28:901-30.

Almeida, H., and M. Campello. 2007. Financial constraints, asset tangibility, and corporate investment. Review of Financial Studies 20:1429-60.

- 2010. Financing frictions and the substitution between internal and external funds. Journal of Financial and Quantitative Analysis 45:589-622.

Almeida, H., M. Campello, and A. F. Galvao, Jr. 2010. Measurement errors in investment equations. Review of Financial Studies 23:3279-328.

Almeida, H., M. Campello, and M. S. Weisbach. 2004. The cash flow sensitivity of cash. Journal of Finance 59:1777-804.

Bansal, R., R. Dittmar, and D. Kiku. 2009. Cointegration and consumption risks in asset returns. Review of Financial Studies 22:1343-75.

Beveridge, S., and C. R. Nelson. 1981. A new approach to decomposition of economic time series into permanent and transitory components with particular attention to measurement of the 'business cycle'. Journal of Monetary Economics 7:151-74.

Bushman, R., A. Smith, and F. Zhang. 2011. Investment cash flow sensitivities really reflect related investment decisions. Working Paper, University of North Carolina at Chapel Hill.

Cleary, S. 1999. The relationship between firm investment and financial status. Journal of Finance 54:673-92.

Cochrane, J. H. 1994. Permanent and transitory components of GNP and stock prices. Quarterly Journal of Economics 109:241-65.

Colak, G., and T. M. Whited. 2007. Spin-offs, divestitures, and conglomerate investment. Review of Financial Studies 20:557-95.

Dasgupta, S., T. H. Noe, and Z. Wang. 2011. Where did all the dollars go? The effect of cash flows on capital and asset structure. Journal of Financial and Quantitative Analysis 46:1259-94.

Dasgupta, S., and K. Sengupta. 2007. Corporate liquidity, investment and financial constraints: Implications from a multi-period model. Journal of Financial Intermediation 16:151-74. 
Erickson, T., and T. M. Whited. 2000. Measurement error and the relationship between investment and q. Journal of Political Economy 108:1027-57.

- 2002. Two-step GMM estimation of the errors-in-variables model using high-order moments. Econometric Theory 18:776-99.

- 2012. Treating measurement error in Tobin's q. Review of Financial Studies 25:1286329.

Fama, E. F., and K. R. French. 2005. Financing decisions: Who issues stock? Journal of Financial Economics 76:549-82.

Fazzari, S. M., R. G. Hubbard, and B. C. Petersen. 1988. Financing constraints and corporate investment. Brookings Papers on Economic Activity 1988:141-206.

- 2000. Investment-cash flow sensitivities are useful: A comment on Kaplan and Zingales. Quarterly Journal of Economics 115:695-705.

Frank, M. Z., and V. K. Goyal. 2003. Testing the pecking order theory of capital structure. Journal of Financial Economics 67:217-48.

Garleanu, N., L. Kogan, and S. Panageas. 2012. Displacement risk and asset returns. Journal of Financial Economics 105:491-510.

Garleanu, N., S. Panageas, and J. Yu. 2012. Technological growth and asset pricing. Journal of Finance 67:1265-92.

Gatchev, V., T. Pulvino, and V. Tarhan. 2010. The interdependent and intertemporal nature of financial decisions: An application to cash flow sensitivities. Journal of Finance 65:725-63.

Gorbenko, A. S., and I. A. Strebulaev. 2010. Temporary versus permanent shocks: Explaining corporate financial policies. Review of Financial Studies 23:2591-647.

Greene, W. H. 2012. Econometric analysis, 7th edition. Upper Saddle River: Prentice-Hall.

Hadlock, C. J., and J. R. Pierce. 2010. New evidence on measuring financial constraints: Moving beyond the KZ index. Review of Financial Studies 23:1909-40.

Hennessy, C. A. 2004. Tobin's Q, debt overhang, and investment. Journal of Finance 59:171742.

Hodrick, R. J., and E. C. Prescott. 1997. Postwar US business cycles: an empirical investigation. Journal of Money, Credit, and Banking 29:1-16.

Hubbard, R. G. 1998. Capital-Market Imperfections and Investment. Journal of Economic Literature 36:193-225. 
Kaplan, S. N., and L. Zingales. 1997. Do investment-cash flow sensitivities provide useful measures of financing constraints? Quarterly Journal of Economics 112: 169-215.

- 2000. Investment-cash flow sensitivities are not valid measures of financing constraints. Quarterly Journal of Economics 115:707-12.

Maravall, A. 1995. Unobserved components in economic time series. In Handbook of applied econometrics, vol. 1: Macroeconomics, 12-72. Eds. H. Pesaran and M. R. Wickens. Oxford, UK: Blackwell.

Morley, J. C. 2002. A state-space approach to calculating the Beveridge-Nelson decomposition. Economics Letters 75:123-7.

Morley, J. C., C. R. Nelson, and E. Zivot. 2003. Why are the Beveridge-Nelson and unobservedcomponents decompositions of GDP so different? Review of Economics and Statistics 85:23543.

Nelson, C. R. 2008. The Beveridge-Nelson decomposition in retrospect and prospect. Journal of Econometrics 146:202-6.

Oh, K. H., E. Zivot, and D. Creal. 2008. The relationship between the Beveridge-Nelson decomposition and other permanent-transitory decompositions that are popular in economics. Journal of Econometrics 146:207-19.

Riddick, L. A., and T. M. Whited. 2009. The corporate propensity to save. Journal of Finance 64:1729-66.

Whited, T. M. 2001. Is it inefficient investment that causes the diversification discount? Journal of Finance 56:1667-91.

- 2006. External finance constraints and the intertemporal pattern of intermittent investment. Journal of Financial Economics 81:467-502.

Whited, T. M., and G. Wu. 2006. Financial constraints risk. Review of Financial Studies 19:53159. 


\section{Table 1. Variables defined using the flow-of-funds data}

Variables are defined using flow-of-funds data of Compustat. The variable definitions vary according to the format code (scf) a firm follows in reporting flow-of-funds data. Effective for fiscal years ending July 15, 1988, SFAS \#95 requires U.S. companies to report the statement of cash flows $(s c f=7)$. Prior to adoption of SFAS \#95, companies may have reported one of the following statements: working capital statement $(s c f=1)$, cash statement by source and use of funds $(s c f=2)$, and cash statement by activity $(s c f=3)$. Variables include the change in cash holdings $(\triangle$ Cash), investment $(I n v)$, the change in working capital $(\triangle W C)$, cash dividends $(D i v)$, cash flow $(C F)$, net debt issued $(\Delta D)$, and net equity issued $(\Delta E)$. The Compustat XPF variable names are italicized and provided in parentheses. PPE denotes property, plant, and equipment.

\begin{tabular}{|c|c|c|c|c|}
\hline Variables & $s c f=1$ & $s c f=2$ & $s c f=3$ & $s c f=7$ \\
\hline $\operatorname{Inv}$ & $\begin{array}{c}\text { capital expenditure }(\text { capx })+\text { increase in } \\
\text { investment }(\text { ivch })+\text { acquisition }(a q c)+\text { other uses of } \\
\text { funds }(\text { fuseo }) \text { - sale of } \operatorname{PPE}(\text { sppe }) \text { - sale of } \\
\text { investment }(\text { siv })\end{array}$ & same as $s c f=1$ & same as $s c f=1$ & $\begin{array}{c}\text { capital expenditure }(\text { capx })+\text { increase in } \\
\text { investment }(\text { ivch })+\text { acquisition }(a q c) \text { - sale of } \\
\text { PPE }(\text { sppe }) \text { - sale of investment }(\text { siv }) \text { - change in short- } \\
\text { term investment }(\text { ivstch }) \text { - other investing } \\
\text { activities }(\text { ivaco })\end{array}$ \\
\hline$\Delta$ Cash & cash and cash equivalents increase/decrease (chech) & same as $s c f=1$ & same as $s c f=1$ & same as $s c f=1$ \\
\hline Div & cash dividends $(d v)$ & same as $s c f=1$ & same as $s c f=1$ & same as $s c f=1$ \\
\hline$\Delta D$ & $\begin{array}{l}\text { long-term debt issuance }(\text { dltis }) \text { - long-term debt } \\
\text { reduction }(d l t r) \text { - changes in current debt }(\text { dlcch })\end{array}$ & $\begin{array}{l}\text { long-term debt issuance }(\text { dltis }) \\
\text { - long-term debt } \\
\text { reduction }(\text { dltr })+\text { changes in } \\
\text { current debt }(\text { dlcch })\end{array}$ & same as $s c f=2$ & same as $s c f=2$ \\
\hline$\Delta E$ & $\begin{array}{l}\text { sale of common and preferred stock (sstk)- } \\
\text { purchase of common and preferred stock }(\text { prstkc) }\end{array}$ & same as $s c f=1$ & same as $s c f=1$ & same as $s c f=1$ \\
\hline$\Delta W C$ & change in working capital(wcapc) & $\begin{array}{l}\text { - change in working } \\
\text { capital }(w c a p c)\end{array}$ & same as $s c f=2$ & $\begin{array}{c}\text {-change in account receivable }(\text { recch }) \text { - change in } \\
\text { inventory }(\text { invch }) \text { - change in account payable (apalch) } \\
\text { - accrued income taxes }(\text { txach }) \text { - other changes in } \\
\text { assets and liabilities (aoloch) - other financing } \\
\text { activities(fiao) }\end{array}$ \\
\hline$C F$ & $\begin{array}{c}\text { income before extra items }(i b c)+\text { extra items \& } \\
\text { discontinued operation }(x i d o c)+\text { depreciation } \& \\
\text { amortization }(d p c)+\text { deferred taxes }(\text { txdc })+\text { equity in } \\
\text { net loss }(e s u b c)+\text { gains in sale of PPE \& } \\
\text { investment }(\text { sppiv })+\text { other funds from } \\
\text { operation }(\text { fopo })+\text { other sources of funds }(\text { ssco })- \\
\Delta W C\end{array}$ & same as $s c f=1$ & same as $s c f=1$ & $\begin{array}{c}\text { income before extra items }(i b c)+\text { extra items \& } \\
\text { discontinued operation }(x i d o c)+\text { depreciation \& } \\
\text { amortization }(d p c)+\text { deferred taxes }(t x d c)+\text { equity in } \\
\text { net loss }(\text { esubc })+\text { gains in sale of PPE \& } \\
\text { investment }(\text { sppiv })+\text { other funds from operation }(\text { fopo }) \\
+ \text { exchange rate effect }(\text { exre })-\Delta W C\end{array}$ \\
\hline
\end{tabular}




\section{Table 2. Summary statistics}

The sample consists of 46,991 firm-years jointly covered in Compustat and CRSP between 1971 and 2011. The variables in the cash-flow identity (Equation (1)) include the change in cash holdings $(\Delta C a s h)$, investment (Inv), cash dividends (Div), cash flow $(C F)$, net debt issued $(\Delta D)$, and net equity issued $(\Delta E)$. They are all deflated by the beginning-of-period total assets. $D I F^{\text {Equation } 1}$ is the difference between the lefthand and right-hand sides of Equation (1). Observations with $\left|D I F^{\text {Equation }}{ }^{1}\right|>1 \%$ are deleted. $C F$ _Cycle and $C_{-}$Trend are the cycle and the trend components of $C F$, respectively. Ln(Assets) is the natural $\log$ of the total book value of assets. $M B$ is defined as the market value of assets divided by the book value of assets. Tangibility is the net PPE over total assets. Sales Growth is the change in net sales scaled by lagged net sales. Leverage is defined as total debt (the sum of short-term and long-term debt) divided by total assets. Dollar values are adjusted to the 2000 dollar value using the gross domestic product (GDP) deflator. Q1 and Q3 stand for the 25th and 75th percentiles of the distribution, respectively. All variables are winsorized at the top and bottom $1 \%$ of their distributions.

\begin{tabular}{|c|c|c|c|c|c|c|c|}
\hline Variables & Mean & $\mathrm{SD}$ & Minimum & Q1 & Median & Q3 & Maximum \\
\hline $\operatorname{Inv}$ & 0.092 & 0.142 & -0.373 & 0.023 & 0.064 & 0.128 & 2.274 \\
\hline$\Delta$ Cash & 0.009 & 0.102 & -0.478 & -0.017 & 0.001 & 0.028 & 2.215 \\
\hline Div & 0.011 & 0.017 & 0 & 0 & 0 & 0.017 & 0.108 \\
\hline$\Delta D$ & 0.014 & 0.110 & -0.550 & -0.022 & 0 & 0.029 & 1.647 \\
\hline$\Delta E$ & 0.016 & 0.115 & -0.146 & -0.002 & 0 & 0.006 & 3.613 \\
\hline$C F$ & 0.083 & 0.118 & -0.752 & 0.029 & 0.088 & 0.147 & 0.705 \\
\hline$D I F^{\text {Equation } 1}$ & 0 & 0.003 & -0.010 & 0 & 0 & 0 & 0.010 \\
\hline CF_Cycle & -0.002 & 0.079 & -0.366 & -0.031 & -0.001 & 0.027 & 0.436 \\
\hline CF_Trend & 0.084 & 0.106 & -0.472 & 0.037 & 0.085 & 0.137 & 0.472 \\
\hline$M B$ & 1.659 & 1.119 & 0.549 & 1.022 & 1.313 & 1.862 & 8.471 \\
\hline SaleG & 0.132 & 0.358 & -0.542 & -0.019 & 0.081 & 0.201 & 2.855 \\
\hline Ln(Assets $)$ & 5.401 & 2.094 & 0.980 & 3.805 & 5.331 & 6.894 & 10.745 \\
\hline Leverage & 0.215 & 0.187 & 0 & 0.042 & 0.192 & 0.332 & 0.797 \\
\hline Tangibility & 0.306 & 0.219 & 0.009 & 0.134 & 0.255 & 0.428 & 0.896 \\
\hline
\end{tabular}




\section{Table 3. The allocation of cash flow}

The data are from Compustat and CRSP for 1971-2011. The dependent variables are five uses of cash flow $(C F)$, including the change in cash holdings $(\Delta C a s h)$, investment $(I n v)$, cash dividends $(D i v)$, net debt issued $(\Delta D)$, and net equity issued $(\Delta E)$. $C F \_C y c l e$ and $C F \_T r e n d$ are the cycle and the trend components of $C F$, respectively. Ln(Assets) is the natural $\log$ of the total book value of assets. $M B$ is defined as the market value of assets divided by the book value of assets. Tangibility is the net PPE over total assets. Sales Growth is the change in net sales scaled by lagged net sales. Leverage is defined as total debt (the sum of short-term and long-term debt) divided by total assets. To estimate regressions with firm fixed effects in both panels, we demean the dependent and all independent variables in the equations. The constant term and year dummies are included in regressions but are not reported. Coefficients significant at the $10 \%, 5 \%$, and $1 \%$ levels are indicated by $*$, **, and ***, respectively. The $t$ statistics are presented in parentheses. Panel A examines how firms allocate the total cash flow. Panel B shows the respective allocations of the trend and cycle components of cash flow.

\begin{tabular}{|c|c|c|c|c|c|c|c|c|c|c|}
\hline \multirow{3}{*}{$\begin{array}{l}\text { Dependent } \\
\text { variables }\end{array}$} & \multicolumn{5}{|c|}{ Panel A: Allocation of $C F$} & \multicolumn{5}{|c|}{ Panel B: Allocation of $C_{-} F_{C}$ Cycle and $C F \_T r e n d$} \\
\hline & $(1)$ & $(2)$ & (3) & (4) & $(5)$ & (6) & (7) & (8) & (9) & (10) \\
\hline & $\operatorname{In} v_{t}$ & $\Delta \operatorname{Cash}_{t}$ & $\operatorname{Div}_{t}$ & $\Delta D_{t}$ & $\Delta E_{t}$ & $\operatorname{In} v_{t}$ & $\Delta$ Cash $_{t}$ & $D i v_{t}$ & $\Delta D_{t}$ & $\Delta E_{t}$ \\
\hline$C F_{t}$ & $\begin{array}{c}0.28 * * * \\
(45.1)\end{array}$ & $\begin{array}{c}0.33 * * * \\
(69.8)\end{array}$ & $\begin{array}{c}0.01 * * * \\
(21.5)\end{array}$ & $\begin{array}{c}-0.28 * * * \\
(-55.4)\end{array}$ & $\begin{array}{c}-0.10 * * * \\
(-20.0)\end{array}$ & & & & & \\
\hline CF_Cycle $F_{t}$ & & & & & & $\begin{array}{c}0.23 * * * \\
(30.0)\end{array}$ & $\begin{array}{c}0.36 * * * \\
(61.8)\end{array}$ & $\begin{array}{c}0.01 * * * \\
(10.9)\end{array}$ & $\begin{array}{c}-0.32 * * * \\
(-50.5)\end{array}$ & $\begin{array}{c}-0.09 * * * \\
(-13.5)\end{array}$ \\
\hline CF_Trend & & & & & & $\begin{array}{c}0.34 * * * \\
(40.6)\end{array}$ & $\begin{array}{c}0.29 * * * \\
(45.4)\end{array}$ & $\begin{array}{c}0.01 * * * \\
(23.2)\end{array}$ & $\begin{array}{c}-0.23 * * * \\
(-34.4)\end{array}$ & $\begin{array}{c}-0.12 * * * \\
(-17.9)\end{array}$ \\
\hline$M B_{t-1}$ & $\begin{array}{c}0.02 * * * \\
(31.6)\end{array}$ & $\begin{array}{c}0.01 * * * \\
(11.9)\end{array}$ & $\begin{array}{c}0.00 * * * \\
(17.9)\end{array}$ & $\begin{array}{c}0.01 * * * \\
(13.4)\end{array}$ & $\begin{array}{c}0.02 * * * \\
(37.2)\end{array}$ & $\begin{array}{c}0.02 * * * \\
(31.4)\end{array}$ & $\begin{array}{c}0.01 * * * \\
(12.1)\end{array}$ & $\begin{array}{c}0.00 * * * \\
(17.7)\end{array}$ & $\begin{array}{c}0.01 * * * \\
(13.2)\end{array}$ & $\begin{array}{c}0.02 * * * \\
(37.3)\end{array}$ \\
\hline Sale $G_{t-1}$ & $\begin{array}{c}0.03 * * * \\
(14.5)\end{array}$ & $\begin{array}{l}0.00 \\
(1.1)\end{array}$ & $\begin{array}{c}-0.00 * * * \\
(-5.8)\end{array}$ & $\begin{array}{c}0.02 * * * \\
(11.4)\end{array}$ & $\begin{array}{l}0.01 * * * \\
(6.7)\end{array}$ & $\begin{array}{c}0.03 * * * \\
(14.8)\end{array}$ & $\begin{array}{l}0.00 \\
(0.8)\end{array}$ & $\begin{array}{c}-0.00 * * * \\
(-5.5)\end{array}$ & $\begin{array}{c}0.02 * * * \\
(11.7)\end{array}$ & $\begin{array}{c}0.01 * * * \\
(6.6)\end{array}$ \\
\hline $\operatorname{Ln}(\text { Assets })_{t-1}$ & $\begin{array}{c}-0.02 * * * \\
(-20.2)\end{array}$ & $\begin{array}{c}-0.01 * * * \\
(-17.6)\end{array}$ & $\begin{array}{c}0.00 * * * \\
(3.5)\end{array}$ & $\begin{array}{c}-0.01 * * * \\
(-8.3)\end{array}$ & $\begin{array}{c}-0.03 * * * \\
(-32.2)\end{array}$ & $\begin{array}{c}-0.02 * * * \\
(-19.0)\end{array}$ & $\begin{array}{c}-0.01 * * * \\
(-18.5)\end{array}$ & $\begin{array}{c}0.00 * * * \\
(4.6)\end{array}$ & $\begin{array}{c}-0.01 * * * \\
(-7.2)\end{array}$ & $\begin{array}{c}-0.03 * * * \\
(-32.5)\end{array}$ \\
\hline Leverage $_{t-1}$ & $\begin{array}{c}-0.15 * * * \\
(-29.6)\end{array}$ & $\begin{array}{c}0.01 * * \\
(2.3)\end{array}$ & $\begin{array}{c}-0.02 * * * \\
(-40.7)\end{array}$ & $\begin{array}{c}-0.22 * * * \\
(-52.8)\end{array}$ & $\begin{array}{c}0.06 * * * \\
(14.8)\end{array}$ & $\begin{array}{c}-0.15 * * * \\
(-28.4)\end{array}$ & $\begin{array}{l}0.01 \\
(1.3)\end{array}$ & $\begin{array}{c}-0.02 * * * \\
(-39.5)\end{array}$ & $\begin{array}{c}-0.22 * * * \\
(-51.6)\end{array}$ & $\begin{array}{c}0.06^{* * * *} \\
(14.2)\end{array}$ \\
\hline Tangibility $_{t-1}$ & $\begin{array}{c}0.04 * * * \\
(5.4)\end{array}$ & $\begin{array}{c}0.07 * * * \\
(13.3)\end{array}$ & $\begin{array}{c}0.00 * * * \\
(3.7)\end{array}$ & $\begin{array}{c}0.07 * * * \\
(12.0)\end{array}$ & $\begin{array}{c}0.04 * * * \\
(7.4)\end{array}$ & $\begin{array}{c}0.03 * * * \\
(4.9)\end{array}$ & $\begin{array}{c}0.08 * * * \\
(13.8)\end{array}$ & $\begin{array}{c}0.00 * * * \\
(3.2)\end{array}$ & $\begin{array}{c}0.07 * * * \\
(11.5)\end{array}$ & $\begin{array}{c}0.04 * * * \\
(7.6)\end{array}$ \\
\hline $\mathrm{N}$ & 46,991 & 46,991 & 46,991 & 46,991 & 46,991 & 46,991 & 46,991 & 46,991 & 46,991 & 46,991 \\
\hline$R^{2}$ & 0.13 & 0.11 & 0.07 & 0.13 & 0.07 & 0.13 & 0.12 & 0.07 & 0.13 & 0.07 \\
\hline
\end{tabular}




\section{Table 4. Financial constraints and the allocation of cash flow}

The data are from Compustat and CRSP for 1971-2011. The dependent variables are five uses of cash flow $(C F)$, including the change in cash holdings $(\triangle C a s h)$, investment $(I n v)$, cash dividends $(D i v)$, net debt issued $(\Delta D)$, and net equity issued $(\Delta E)$. $C F \_C y c l e$ and $C F_{-}$Trend are the cycle and the trend components of $C F$, respectively. Each year a firm is classified as financially more constrained if its $\operatorname{Ln}($ Assets) is below the 30th percentile, its $H P$ index or the $W W$ index is above the 70th percentile, it pays no dividends, or it has no credit rating. A firm is classified as financially less constrained if its $\operatorname{Ln}($ Assets) is above the 70th percentile, its $H P$ index or the $W W$ index is below the 30 th percentile, it pays dividends, or it has a credit rating. The models in Table 3 are estimated separately for more and less constrained subsamples. All control variables in Table 3 are included in the regressions. Only the coefficients of $C F$ (panel A) and the two $C F$ components (panel B) are reported for brevity. To estimate the regressions with firm fixed effects in both panels, we demean the dependent and all independent variables in the equations. The constant term and year dummies are included in regressions but are not reported. Coefficients significant at the $10 \%, 5 \%$, and $1 \%$ levels are indicated by $* * *$, and $* * *$, respectively. The $t$-statistics are presented in parentheses.

Panel A: Allocation of $\boldsymbol{C F}$

\begin{tabular}{|c|c|c|c|c|c|c|c|c|c|c|c|}
\hline \multirow[b]{2}{*}{$\begin{array}{l}\text { Constraint } \\
\text { measures: }\end{array}$} & & \multicolumn{5}{|c|}{ More constrained firms } & \multicolumn{5}{|c|}{ Less constrained firms } \\
\hline & & $\begin{array}{l}(1) \\
\operatorname{In} v_{t}\end{array}$ & $\begin{array}{c}(2) \\
\Delta \operatorname{Cash}_{t}\end{array}$ & $\begin{array}{c}(3) \\
\text { Div } \\
\end{array}$ & $\begin{array}{c}(4) \\
\Delta D_{t}\end{array}$ & $\begin{array}{l}(5) \\
\Delta E_{t} \\
\end{array}$ & $\begin{array}{l}(6) \\
\operatorname{In} v_{t} \\
\end{array}$ & $\begin{array}{c}(7) \\
\Delta \operatorname{Cash}_{t}\end{array}$ & $\begin{array}{c}(8) \\
\text { Div }_{t}\end{array}$ & $\begin{array}{c}(9) \\
\Delta D_{t}\end{array}$ & $\begin{array}{l}(10) \\
\Delta E_{t}\end{array}$ \\
\hline Ln(Assets $)$ & $C F_{t}$ & $\begin{array}{l}0.21^{\text {*** }} \\
(24.2)\end{array}$ & $\begin{array}{c}0.38^{* * * *} \\
(46.6)\end{array}$ & $\begin{array}{l}0.01^{* * *} \\
(10.0)\end{array}$ & $\begin{array}{l}-0.28^{* * *} \\
(-41.4)\end{array}$ & $\begin{array}{l}-0.12^{* * *} \\
(-14.0)\end{array}$ & $\begin{array}{l}0.45^{\text {**** }} \\
(27.3)\end{array}$ & $\begin{array}{c}0.24^{\text {**** }} \\
(29.3)\end{array}$ & $\begin{array}{c}0.02^{* * *} \\
(13.9)\end{array}$ & $\begin{array}{l}-0.25^{* * *} \\
(-17.7)\end{array}$ & $\begin{array}{c}-0.04^{* * *} \\
(-5.4)\end{array}$ \\
\hline HP Index & $C F_{t}$ & $\begin{array}{l}0.24^{* * * *} \\
(24.1)\end{array}$ & $\begin{array}{c}0.37^{\text {**** }} \\
(41.0)\end{array}$ & $\begin{array}{c}0.01^{* * *} \\
(9.3)\end{array}$ & $\begin{array}{l}-0.27^{* * *} \\
(-35.9)\end{array}$ & $\begin{array}{l}-0.12^{* * *} \\
(-10.7)\end{array}$ & $\begin{array}{l}0.38^{* * * *} \\
(27.0)\end{array}$ & $\begin{array}{c}0.26^{\text {**** }} \\
(33.6)\end{array}$ & $\begin{array}{c}0.02^{* * *} \\
(15.4)\end{array}$ & $\begin{array}{l}-0.29^{* * *} \\
(-23.1)\end{array}$ & $\begin{array}{c}-0.05^{\text {**** }} \\
(-8.8)\end{array}$ \\
\hline WW Index & $C F_{t}$ & $\begin{array}{l}0.20^{* * *} \\
(22.7)\end{array}$ & $\begin{array}{c}0.36^{* * * *} \\
(43.9)\end{array}$ & $\begin{array}{c}0.00^{* * *} \\
(8.7)\end{array}$ & $\begin{array}{c}-0.29^{* * *} \\
(-41.2)\end{array}$ & $\begin{array}{l}-0.15^{* * *} \\
(-16.2)\end{array}$ & $\begin{array}{l}0.45^{* * *} \\
(26.9)\end{array}$ & $\begin{array}{c}0.26^{\text {**** }} \\
(32.6)\end{array}$ & $\begin{array}{c}0.02^{* * *} \\
(15.3)\end{array}$ & $\begin{array}{l}-0.23^{* * *} \\
(-16.4)\end{array}$ & $\begin{array}{c}-0.04^{* * *} \\
(-5.1)\end{array}$ \\
\hline Dividend Payer & $C F_{t}$ & $\begin{array}{l}0.26^{* * * *} \\
(34.2)\end{array}$ & $\begin{array}{c}0.35^{\text {*** }} \\
(52.4)\end{array}$ & $\begin{array}{c}0.00^{* * *} \\
(9.0)\end{array}$ & $\begin{array}{l}-0.27^{* * *} \\
(-44.5)\end{array}$ & $\begin{array}{l}-0.11^{* * *} \\
(-14.3)\end{array}$ & $\begin{array}{l}0.32^{\text {*** }} \\
(29.0)\end{array}$ & $\begin{array}{c}0.30^{* * *} \\
(49.6)\end{array}$ & $\begin{array}{c}0.02^{* * * *} \\
(20.6)\end{array}$ & $\begin{array}{l}-0.31^{* * *} \\
(-31.9)\end{array}$ & $\begin{array}{c}-0.05^{\text {*** }} \\
(-9.3)\end{array}$ \\
\hline Credit Rating & $C F_{t}$ & $\begin{array}{l}0.26^{* * *} \\
(38.7)\end{array}$ & $\begin{array}{l}0.35^{* * *} \\
(63.4)\end{array}$ & $\begin{array}{l}0.01^{\text {*** }} \\
(17.1)\end{array}$ & $\begin{array}{l}-0.28^{* * *} \\
(-54.8)\end{array}$ & $\begin{array}{l}-0.10^{* * *} \\
(-17.2)\end{array}$ & $\begin{array}{l}0.43^{\text {*** }} \\
(24.1)\end{array}$ & $\begin{array}{l}0.23^{* * *} \\
(23.4)\end{array}$ & $\begin{array}{l}0.02^{* * *} \\
(12.4)\end{array}$ & $\begin{array}{l}-0.27^{* * *} \\
(-16.6)\end{array}$ & $\begin{array}{c}-0.04^{* * *} \\
(-5.3)\end{array}$ \\
\hline
\end{tabular}




\section{Table 4 (Continued)}

Panel B: Allocation of $C F \_C y c l e$ and $C F \_T r e n d$

\begin{tabular}{|c|c|c|c|c|c|c|c|c|c|c|c|}
\hline \multirow{3}{*}{$\begin{array}{l}\text { Constraint } \\
\text { measures: }\end{array}$} & & \multirow{2}{*}{\multicolumn{5}{|c|}{ More constra }} & \multicolumn{5}{|c|}{ Less constrained firms } \\
\hline & & (1) & $(2)$ & & & & $(6)$ & $(7)$ & $(8)$ & $(9)$ & $(10)$ \\
\hline & & $\operatorname{In} v_{t}$ & $\Delta$ Cash $_{t}$ & $\operatorname{Div}_{t}$ & $\Delta D_{t}$ & $\Delta E_{t}$ & $\operatorname{In} v_{t}$ & $\Delta \operatorname{Cash}_{t}$ & $\operatorname{Div}_{t}$ & $\Delta D_{t}$ & $\Delta E_{t}$ \\
\hline \multirow[t]{2}{*}{ Ln(Assets $)$} & $C F_{-} C y c l e_{t}$ & $\begin{array}{l}0.18^{* * *} \\
(16.9)\end{array}$ & $\begin{array}{l}0.41^{\text {*** }} \\
(41.2)\end{array}$ & $\begin{array}{c}0.00^{\text {*** }} \\
(5.9)\end{array}$ & $\begin{array}{l}-0.30^{* * *} \\
(-36.5)\end{array}$ & $\begin{array}{c}-0.10^{* * *} \\
(-9.5)\end{array}$ & $\begin{array}{l}0.35^{* * *} \\
(16.5)\end{array}$ & $\begin{array}{l}0.27^{\text {*** }} \\
(25.7)\end{array}$ & $\begin{array}{c}0.01^{\text {**** }} \\
(6.3)\end{array}$ & $\begin{array}{l}-0.33^{\text {*** }} \\
(-18.0)\end{array}$ & $\begin{array}{c}-0.04^{* * *} \\
(-4.0)\end{array}$ \\
\hline & $C F_{-}$Trend $_{t}$ & $\begin{array}{l}0.26^{* * * *} \\
(20.8)\end{array}$ & $\begin{array}{l}0.33^{* * * *} \\
(29.3)\end{array}$ & $\begin{array}{c}0.01^{\text {**** }} \\
(9.9)\end{array}$ & $\begin{array}{l}-0.25^{* * *} \\
(-26.2)\end{array}$ & $\begin{array}{l}-0.15^{* * *} \\
(-12.3)\end{array}$ & $\begin{array}{l}0.54^{* * * *} \\
(26.6)\end{array}$ & $\begin{array}{l}0.21^{* * * *} \\
(21.0)\end{array}$ & $\begin{array}{l}0.02^{* * * *} \\
(15.4)\end{array}$ & $\begin{array}{l}-0.19^{* * *} \\
(-10.5)\end{array}$ & $\begin{array}{c}-0.04^{* * *} \\
(-4.6)\end{array}$ \\
\hline \multirow[t]{2}{*}{ HP Index } & $C F_{-} C y c l e_{t}$ & $\begin{array}{c}0.20^{\text {**** }} \\
(16.5)\end{array}$ & $\begin{array}{l}0.40^{* * *} \\
(35.1)\end{array}$ & $\begin{array}{c}0.00^{\text {**** }} \\
(5.9)\end{array}$ & $\begin{array}{l}-0.29^{* * *} \\
(-30.9)\end{array}$ & $\begin{array}{c}-0.10^{* * *} \\
(-7.6)\end{array}$ & $\begin{array}{c}0.29^{* * *} \\
(16.5)\end{array}$ & $\begin{array}{l}0.30^{\text {**** }} \\
(31.9)\end{array}$ & $\begin{array}{c}0.01^{\text {**** }} \\
(7.5)\end{array}$ & $\begin{array}{l}-0.36^{* * *} \\
(-23.4)\end{array}$ & $\begin{array}{c}-0.04^{* * *} \\
(-5.2)\end{array}$ \\
\hline & $C F_{-}$Trend $_{t}$ & $\begin{array}{l}0.28^{* * * *} \\
(20.9)\end{array}$ & $\begin{array}{l}0.34^{* * * *} \\
(27.6)\end{array}$ & $\begin{array}{c}0.01^{\text {**** }} \\
(8.6)\end{array}$ & $\begin{array}{l}-0.24^{* * * *} \\
(-23.9)\end{array}$ & $\begin{array}{c}-0.13^{* * *} \\
(-9.0)\end{array}$ & $\begin{array}{c}0.49^{* * * *} \\
(26.6)\end{array}$ & $\begin{array}{l}0.21^{* * *} \\
(20.6)\end{array}$ & $\begin{array}{l}0.03^{* * * *} \\
(17.2)\end{array}$ & $\begin{array}{c}-0.20^{* * *} \\
(-12.5)\end{array}$ & $\begin{array}{c}-0.07^{* * *} \\
(-8.9)\end{array}$ \\
\hline \multirow[t]{2}{*}{ WW Index } & CF_Cycle $e_{t}$ & $\begin{array}{c}0.17^{\text {*** }} \\
(16.2)\end{array}$ & $\begin{array}{l}0.39^{* * *} \\
(39.4)\end{array}$ & $\begin{array}{c}0.00^{\text {*** }} \\
(5.3)\end{array}$ & $\begin{array}{l}-0.32^{* * *} \\
(-36.9)\end{array}$ & $\begin{array}{l}-0.12^{* * *} \\
(-10.8)\end{array}$ & $\begin{array}{l}0.35^{\text {*** }} \\
(16.2)\end{array}$ & $\begin{array}{l}0.29^{* * *} \\
(27.8)\end{array}$ & $\begin{array}{c}0.01^{\text {**** }} \\
(7.9)\end{array}$ & $\begin{array}{l}-0.31^{\text {*** }} \\
(-16.9)\end{array}$ & $\begin{array}{c}-0.03^{* * *} \\
(-3.8)\end{array}$ \\
\hline & CF_Trend & $\begin{array}{c}0.24^{* * *} \\
(19.3)\end{array}$ & $\begin{array}{l}0.31^{\text {*** }} \\
(27.3)\end{array}$ & $\begin{array}{c}0.01^{\text {**** }} \\
(8.5)\end{array}$ & $\begin{array}{l}-0.26^{* * *} \\
(-25.7)\end{array}$ & $\begin{array}{l}-0.18^{* * *} \\
(-14.6)\end{array}$ & $\begin{array}{l}0.53^{* * *} \\
(26.2)\end{array}$ & $\begin{array}{l}0.24^{\text {*** }} \\
(24.6)\end{array}$ & $\begin{array}{l}0.03^{* * * *} \\
(16.1)\end{array}$ & $\begin{array}{c}-0.17^{* * * *} \\
(-9.7)\end{array}$ & $\begin{array}{c}-0.04^{* * *} \\
(-4.4)\end{array}$ \\
\hline \multirow[t]{2}{*}{ Dividend Payer } & CF_Cycle $e_{t}$ & $\begin{array}{l}0.22^{* * *} \\
(23.2)\end{array}$ & $\begin{array}{l}0.38^{* * *} \\
(45.9)\end{array}$ & $\begin{array}{c}0.00^{\text {**** }} \\
(4.9)\end{array}$ & $\begin{array}{l}-0.30^{* * *} \\
(-39.8)\end{array}$ & $\begin{array}{l}-0.09^{* * *} \\
(-10.1)\end{array}$ & $\begin{array}{c}0.26^{* * * *} \\
(18.7)\end{array}$ & $\begin{array}{c}0.33^{* * * *} \\
(43.9)\end{array}$ & $\begin{array}{c}0.01^{\text {**** }} \\
(10.5)\end{array}$ & $\begin{array}{l}-0.36^{* * *} \\
(-30.6)\end{array}$ & $\begin{array}{c}-0.03^{\text {*** }} \\
(-5.7)\end{array}$ \\
\hline & CF_Trend & $\begin{array}{c}0.32^{* * * *} \\
(30.2)\end{array}$ & $\begin{array}{l}0.31^{\text {**** }} \\
(34.2)\end{array}$ & $\begin{array}{c}0.00^{\text {**** }} \\
(9.4)\end{array}$ & $\begin{array}{l}-0.24^{* * * *} \\
(-28.0)\end{array}$ & $\begin{array}{l}-0.13^{* * *} \\
(-12.1)\end{array}$ & $\begin{array}{c}0.40^{* * * *} \\
(27.5)\end{array}$ & $\begin{array}{c}0.27^{\text {**** }} \\
(33.8)\end{array}$ & $\begin{array}{l}0.03^{\text {**** }} \\
(22.5)\end{array}$ & $\begin{array}{l}-0.24^{* * * *} \\
(-19.2)\end{array}$ & $\begin{array}{c}-0.06^{* * *} \\
(-9.2)\end{array}$ \\
\hline \multirow[t]{2}{*}{ Credit Rating } & CF_Cycle $e_{t}$ & $\begin{array}{l}0.21^{* * *} \\
(26.1)\end{array}$ & $\begin{array}{c}0.38^{* * *} \\
(55.5)\end{array}$ & $\begin{array}{c}0.01^{\text {*** }} \\
(8.9)\end{array}$ & $\begin{array}{l}-0.32^{* * *} \\
(-49.4)\end{array}$ & $\begin{array}{c}-0.09^{* * *} \\
(-11.9)\end{array}$ & $\begin{array}{c}0.36^{* * *} \\
(16.0)\end{array}$ & $\begin{array}{c}0.27^{\text {*** }} \\
(21.6)\end{array}$ & $\begin{array}{c}0.01^{\text {*** }} \\
(6.2)\end{array}$ & $\begin{array}{c}-0.32^{\text {*** }} \\
(-15.2)\end{array}$ & $\begin{array}{c}-0.04^{* * *} \\
(-3.9)\end{array}$ \\
\hline & CF_Trend & $\begin{array}{l}0.31^{\text {**** }} \\
(34.5)\end{array}$ & $\begin{array}{l}0.31^{\text {*** }} \\
(41.6)\end{array}$ & $\begin{array}{l}0.01^{\text {**** }} \\
(18.2)\end{array}$ & $\begin{array}{l}-0.24^{* * * *} \\
(-34.3)\end{array}$ & $\begin{array}{l}-0.12^{* * *} \\
(-15.0)\end{array}$ & $\begin{array}{l}0.51^{* * * *} \\
(22.2)\end{array}$ & $\begin{array}{c}0.19^{* * *} \\
(15.3)\end{array}$ & $\begin{array}{l}0.02^{\text {**** }} \\
(13.4)\end{array}$ & $\begin{array}{l}-0.23^{* * * *} \\
(-11.0)\end{array}$ & $\begin{array}{c}-0.05^{* * *} \\
(-4.5)\end{array}$ \\
\hline
\end{tabular}




\section{Table 5. Additional analysis and robustness checks}

The dependent variables are five uses of cash flow $(C F)$, including the change in cash holdings $(\triangle C a s h)$, investment $(I n v)$, cash dividends $(D i v)$, net debt issued $(\Delta D)$, and net equity issued $(\Delta E)$. CF_Cycle and $C F \_$Trend are the cycle and the trend components of $C F$, respectively. Firms are classified into financially more and less constrained groups using firm size. The constant term, year dummies, and the control variables in Table 3 are included in the estimation, but their coefficients are not reported. To estimate the regressions with firm fixed effects in both panels, we demean the dependent and all independent variables in the equations. Panel A investigates intertemporal allocation of cash flow by including two lags of the cash flow components. Panel B examines the asymmetry in the cash-flow allocation by including $N E G$, which is a dummy variable that equals one if $C F$ is negative and zero otherwise, and the interaction terms between $N E G$ and the two cash-flow components. Coefficients significant at the $10 \%, 5 \%$, and $1 \%$ levels are indicated by $* * *$, and $* * *$, respectively. The $t$-statistics are not reported.

\begin{tabular}{|c|c|c|c|c|c|c|}
\hline Samples & Variables & $\begin{array}{l}(1) \\
\text { Inv }_{t}\end{array}$ & $\begin{array}{c}(2) \\
\Delta \text { Cash }_{t}\end{array}$ & $\begin{array}{l}\text { (3) } \\
\text { Div }_{t}\end{array}$ & $\begin{array}{c}(4) \\
\Delta D_{t}\end{array}$ & $\begin{array}{c}(5) \\
\Delta E_{t}\end{array}$ \\
\hline \multicolumn{7}{|c|}{ Panel A: Controlling for lagged cash flow } \\
\hline \multirow[t]{6}{*}{ Full sample } & CF_Cycle $e_{t}$ & $0.23 * * *$ & $0.37 * * *$ & $0.01 * * *$ & $-0.31 * * *$ & $-0.08 * * *$ \\
\hline & CF_Trend & $0.31 * * *$ & $0.30 * * *$ & $0.01 * * *$ & $-0.25 * * *$ & $-0.12 * * *$ \\
\hline & $C F_{-} C y c l e_{t-1}$ & $0.03 * * *$ & $-0.03 * * *$ & $0.00 * * *$ & $0.01 * *$ & -0.00 \\
\hline & CF_Trend & $0.05 * * *$ & $-0.02 * * *$ & $0.00 * * *$ & $0.03 * * *$ & 0.01 \\
\hline & CF_Cycle $e_{t-2}$ & $0.01 * * *$ & $-0.00 * * *$ & $0.00 * * *$ & $0.01 * * *$ & $-0.00 * *$ \\
\hline & CF_Trend $d_{t-2}$ & $0.00 * * *$ & -0.00 & $0.00 * *$ & $0.00 * * *$ & -0.00 \\
\hline \multirow[t]{6}{*}{ More constrained } & CF_Cycle $e_{t}$ & $0.18 * * *$ & $0.41 * * *$ & $0.00 * * *$ & $-0.30 * * *$ & $-0.10 * * *$ \\
\hline & CF_Trend $t$ & $0.24 * * *$ & $0.33 * * *$ & $0.01 * * *$ & $-0.26 * * *$ & $-0.15^{* * *}$ \\
\hline & $C F_{-} C y c l e_{t-1}$ & $0.02 * * *$ & $-0.02 * * *$ & $0.00 * * *$ & 0.00 & 0.00 \\
\hline & CF_Trend $d_{t-1}$ & $0.03 * * *$ & -0.00 & $0.00 * * *$ & $0.01 * *$ & 0.01 \\
\hline & $C F \_C y c l e_{t-2}$ & 0.00 & $-0.01 * *$ & 0.00 & 0.00 & $-0.01 * *$ \\
\hline & CF_Trend $_{t-2}$ & 0.00 & -0.00 & 0.00 & 0.00 & -0.00 \\
\hline \multirow[t]{6}{*}{ Less constrained } & CF_Cycle $e_{t}$ & $0.36 * * *$ & $0.27 * * *$ & $0.01 * * *$ & $-0.33 * * *$ & $-0.04 * * *$ \\
\hline & CF_Trend $t$ & $0.49 * * *$ & $0.24 * * *$ & $0.02 * * *$ & $-0.21 * * *$ & $-0.03 * * *$ \\
\hline & CF_Cycle ${ }_{t-1}$ & $0.08 * * *$ & $-0.04 * * *$ & $0.00 * * *$ & $0.05 * * *$ & -0.01 \\
\hline & CF_Trend ${ }_{t-1}$ & $0.08 * * *$ & $-0.06 * * *$ & $0.00 * * *$ & $0.04 * * *$ & $-0.01 *$ \\
\hline & CF_Cycle $t_{t-2}$ & $0.03 * * *$ & $0.01 *$ & 0.00 & $0.04 * * *$ & -0.00 \\
\hline & CF_Trend $t_{t-2}$ & $0.05 * * *$ & -0.00 & 0.00 & $0.05 * * *$ & -0.00 \\
\hline \multicolumn{7}{|c|}{ Panel B: Asymmetries in cash flow allocations between positive and negative $C F$ years } \\
\hline \multirow{5}{*}{ Full sample } & CF_Cycle ${ }_{t}$ & $0.35 * * *$ & $0.43 * * *$ & $0.01 * * *$ & $-0.21 * * *$ & 0.01 \\
\hline & CF_Trend $t$ & $0.47 * * *$ & $0.35 * * *$ & $0.02 * * *$ & $-0.14 * * *$ & $-0.02 *$ \\
\hline & Cycle $_{t} \times N E G_{t}$ & $-0.30 * * *$ & $-0.23 * * *$ & $-0.01 * * *$ & $-0.21 * * *$ & $-0.33 * * *$ \\
\hline & Trend $_{t} \times N E G_{t}$ & $-0.34 * * *$ & $-0.21 * * *$ & $-0.02 * * *$ & $-0.18 * * *$ & $-0.38 * * *$ \\
\hline & $N E G_{t}$ & $0.01 * * *$ & $-0.01 * * *$ & $0.00 * * *$ & $0.02 * * *$ & $-0.01 * * *$ \\
\hline \multirow[t]{5}{*}{ More constrained } & CF_Cycle $e_{t}$ & $0.28 * * *$ & $0.54 * * *$ & $0.01 * * *$ & $-0.21 * * *$ & $0.03^{*}$ \\
\hline & CF_Trend ${ }_{t}$ & $0.39 * * *$ & $0.49 * * *$ & $0.01 * * *$ & $-0.16 * * *$ & $0.05^{* *}$ \\
\hline & Cycle $_{t} \times N E G_{t}$ & $-0.19 * * *$ & $-0.32 * * *$ & $-0.01 * * *$ & $-0.16 * * *$ & $-0.36^{* * *}$ \\
\hline & Trend $_{t} \times N E G_{t}$ & $-0.26 * * *$ & $-0.35 * * *$ & $-0.01 * * *$ & $-0.14 * * *$ & $-0.49 * * *$ \\
\hline & $N E G_{t}$ & 0.01 & 0.00 & 0.00 & $0.01 * * *$ & $-0.01 *$ \\
\hline \multirow[t]{5}{*}{ Less constrained } & CF_Cycle & $0.45 * * *$ & $0.29 * * *$ & $0.01 * * *$ & $-0.22 * * *$ & $-0.02 * *$ \\
\hline & $C F \_$Trend $t$ & $0.58 * * *$ & $0.22 * * *$ & $0.03 * * *$ & $-0.13 * * *$ & $-0.03 * * *$ \\
\hline & Cycle $_{t} \times N E G_{t}$ & $-0.92 * * *$ & $-0.20 * * *$ & $-0.02 * *$ & $-0.97 * * *$ & $-0.16^{* * *}$ \\
\hline & Trend $_{t} \times N E G_{t}$ & $-0.68 * * *$ & $-0.19 * * *$ & $-0.03 * * *$ & $-0.72 * * *$ & $-0.18 * * *$ \\
\hline & $N E G_{t}$ & -0.00 & 0.00 & 0.00 & -0.00 & -0.00 \\
\hline
\end{tabular}




\section{Table 6. Coefficients of $C F$ and $M B$ estimated using GMM estimators}

The data are from Compustat and CRSP for 1971-2011. The dependent variables are five uses of cash flow $(C F)$, including the change in cash holdings $(\Delta C a s h)$, investment $(I n v)$, cash dividends $(D i v)$, net debt issued $(\Delta D)$, and net equity issued $(\Delta E)$. Each year we estimate Equations $(2)-$ (6) using GMM3, GMM4, and GMM5, which are defined in Appendix B. All control variables in Table 3 are included in the estimation. Only the coefficients of $C F$ and $M B$ are reported. We use the minimum distance method to aggregate yearly coefficient estimates. To account for the firm fixed effects, we apply the within transformation to the data and report the results in panel A. Panel B reports the results obtained using data in the level form. Standard errors are included in parentheses. Sum is the sum of the coefficients of $M B$ or $C F$ across five equations.

\begin{tabular}{|c|c|c|c|c|c|c|c|c|c|c|c|c|}
\hline & \multicolumn{6}{|c|}{ Coefficients of $M B$} & \multicolumn{6}{|c|}{ Coefficients of $C F$} \\
\hline & $\operatorname{Inv}$ & $\Delta$ Cash & Div & $\Delta D$ & $\Delta E$ & Sum & $\operatorname{Inv}$ & $\Delta$ Cash & Div & $\Delta D$ & $\Delta E$ & Sum \\
\hline \multicolumn{13}{|c|}{ Panel A: Within transformation form } \\
\hline GMM3 & $\begin{array}{r}-88.31 \\
(0.00)\end{array}$ & $\begin{array}{c}0.03 \\
(0.01)\end{array}$ & $\begin{array}{c}0.00 \\
(0.00)\end{array}$ & $\begin{array}{c}38.9 \\
(0.00)\end{array}$ & $\begin{array}{r}-19.73 \\
(0.00)\end{array}$ & -107.46 & $\begin{array}{c}0.26 \\
(0.02)\end{array}$ & $\begin{array}{c}0.16 \\
(0.02)\end{array}$ & $\begin{array}{c}0.01 \\
(0.00)\end{array}$ & $\begin{array}{l}-0.28 \\
(0.02)\end{array}$ & $\begin{array}{l}-0.09 \\
(0.01)\end{array}$ & 0.79 \\
\hline GMM4 & $\begin{array}{c}-2.92 \\
(0.00)\end{array}$ & $\begin{array}{c}0.05 \\
(0.00)\end{array}$ & $\begin{array}{c}0.00 \\
(0.00)\end{array}$ & $\begin{array}{l}-4.04 \\
(0.00)\end{array}$ & $\begin{array}{l}-9.54 \\
(0.00)\end{array}$ & 10.71 & $\begin{array}{c}0.25 \\
(0.01)\end{array}$ & $\begin{array}{c}0.22 \\
(0.01)\end{array}$ & $\begin{array}{c}0.01 \\
(0.00)\end{array}$ & $\begin{array}{l}-0.28 \\
(0.01)\end{array}$ & $\begin{array}{l}-0.10 \\
(0.01)\end{array}$ & 0.86 \\
\hline GMM5 & $\begin{array}{c}0.08 \\
(0.00)\end{array}$ & $\begin{array}{c}0.00 \\
(0.00)\end{array}$ & $\begin{array}{c}0.00 \\
(0.00)\end{array}$ & $\begin{array}{c}2.34 \\
(0.00)\end{array}$ & $\begin{array}{c}0.00 \\
(0.00)\end{array}$ & -2.26 & $\begin{array}{c}0.25 \\
(0.01)\end{array}$ & $\begin{array}{c}0.20 \\
(0.01)\end{array}$ & $\begin{array}{c}0.01 \\
(0.00)\end{array}$ & $\begin{array}{c}-0.24 \\
(0.01)\end{array}$ & $\begin{array}{l}-0.11 \\
(0.01)\end{array}$ & 0.81 \\
\hline \multicolumn{13}{|c|}{ Panel B: Level form } \\
\hline GMM3 & $\begin{array}{c}0.11 \\
(0.01)\end{array}$ & $\begin{array}{c}0.11 \\
(0.01)\end{array}$ & $\begin{array}{c}0.02 \\
(0.00)\end{array}$ & $\begin{array}{c}0.04 \\
(0.01)\end{array}$ & $\begin{array}{c}0.17 \\
(0.01)\end{array}$ & 0.02 & $\begin{array}{c}0.27 \\
(0.02)\end{array}$ & $\begin{array}{c}0.09 \\
(0.02)\end{array}$ & $\begin{array}{c}0.01 \\
(0.00)\end{array}$ & $\begin{array}{l}-0.19 \\
(0.02)\end{array}$ & $\begin{array}{c}-0.23 \\
(0.02)\end{array}$ & 0.79 \\
\hline GMM4 & $\begin{array}{l}-6.27 \\
(0.00)\end{array}$ & $\begin{array}{l}-5.50 \\
(0.00)\end{array}$ & $\begin{array}{c}0.00 \\
(0.00)\end{array}$ & $\begin{array}{c}0.69 \\
(0.00)\end{array}$ & $\begin{array}{c}3.00 \\
(0.00)\end{array}$ & -15.45 & $\begin{array}{c}0.29 \\
(0.02)\end{array}$ & $\begin{array}{c}0.15 \\
(0.01)\end{array}$ & $\begin{array}{c}0.02 \\
(0.00)\end{array}$ & $\begin{array}{l}-0.19 \\
(0.01)\end{array}$ & $\begin{array}{l}-0.21 \\
(0.02)\end{array}$ & 0.85 \\
\hline GMM5 & $\begin{array}{l}-4.52 \\
(0.00)\end{array}$ & $\begin{array}{c}1.28 \\
(0.00)\end{array}$ & $\begin{array}{c}-0.48 \\
(0.00)\end{array}$ & $\begin{array}{c}0.00 \\
(0.00)\end{array}$ & $\begin{array}{l}-1.26 \\
(0.00)\end{array}$ & -2.46 & $\begin{array}{c}0.29 \\
(0.02)\end{array}$ & $\begin{array}{c}0.18 \\
(0.01)\end{array}$ & $\begin{array}{c}0.02 \\
(0.00)\end{array}$ & $\begin{array}{l}-0.21 \\
(0.01)\end{array}$ & $\begin{array}{l}-0.09 \\
(0.01)\end{array}$ & 0.79 \\
\hline
\end{tabular}




\section{Appendix A. The BN Decomposition}

To implement the $\mathrm{BN}$ decomposition, $\Delta y_{t}$ is fitted using an $\operatorname{ARMA}(p, q)$ model. Then the trend/cycle components are calculated using Equations (11) and (13). However, the calculation process of trend and cycle components is often complicated as the limiting forecast in Equation (11) contains infinite sums. Morley (2002) simplifies the calculation of BN decomposition by applying the state-space approach to the forecasting model for $\left(\Delta y_{t}-\mu\right)$. Specifically, suppose $\left(\Delta y_{t}-\mu\right)$ is a liner combination of the elements of a $k \times 1$ state vector $X_{t}$ :

$$
\left(\Delta y_{t}-\mu\right)=\left[h_{1}, h_{2} \ldots h_{k}\right] X_{t},
$$

where $X_{t}$ is modeled as the first-order stochastic difference equation: $X_{t}=F X_{t-1}+\eta_{t}$ and $\eta_{t} \sim N(0, \Omega)$. All of the eigenvalues of $F$ are less than unity and $F$ is invertible. Then the expected $j$-period-ahead forecast of the $\left(\Delta y_{t}-\mu\right)$ is

$$
E_{t}\left[\left(\Delta y_{t+j}-\mu\right)\right]=\left[h_{1}, h_{2} \ldots h_{k}\right] F^{j} E_{t}\left[X_{t}\right] .
$$

$E_{t}\left[X_{t}\right]$ can be obtained via Kalman filter, and the filtered estimate is denoted as $X_{t \mid t}$. Applying (A2) directly into the definition of trend component (11), we can have the general form of BN trend as

$$
\tau_{t}=y_{t}+\left[h_{1}, h_{2} \ldots h_{k}\right] F(1-F)^{-1} X_{t \mid t} .
$$

Thus, the general form of BN cycle is written as

$$
c_{t}=y_{t}-\tau_{t}=-\left[h_{1}, h_{2} \ldots h_{k}\right] F(1-F)^{-1} X_{t \mid t} .
$$

Following Morley, Nelson, and Zivot (2003), we calculate the BN decomposition by fitting the first difference of unscaled cash flow series with an $\operatorname{ARMA}(2,2)$ model

$$
\left(\Delta y_{t}-\mu\right)=\phi_{1}\left(\Delta y_{t-1}-\mu\right)+\phi_{2}\left(\Delta y_{t-2}-\mu\right)+\varepsilon_{t}+\theta_{1} \varepsilon_{t-1}+\theta_{2} \varepsilon_{t-2}, \quad \varepsilon_{t} \sim \text { i.i.d. } N\left(0, \sigma^{2}\right) \text {. }
$$

The calculation of $\operatorname{ARMA}(2,2)$ is straightforward because it has $\left(\Delta y_{t}-\mu\right)$ as the first element of the state vector $X_{t}$ :

$$
\left[\begin{array}{c}
\Delta y_{t}-\mu \\
\Delta y_{t-1}-\mu \\
\varepsilon_{t} \\
\varepsilon_{t-1}
\end{array}\right]=\left[\begin{array}{cccc}
\phi_{1} & \phi_{2} & \theta_{1} & \theta_{2} \\
1 & 0 & 0 & 0 \\
0 & 0 & 0 & 0 \\
0 & 0 & 1 & 0
\end{array}\right]\left[\begin{array}{c}
\Delta y_{t-1}-\mu \\
\Delta y_{t-2}-\mu \\
\varepsilon_{t-1} \\
\varepsilon_{t-2}
\end{array}\right]+\left[\begin{array}{c}
\varepsilon_{t} \\
0 \\
\varepsilon_{t} \\
0
\end{array}\right]
$$

Then the BN trend of unscaled cash flow $y_{t}$ is

$$
\tau_{t}=y_{t}+\left[\begin{array}{llll}
1 & 0 & 0 & 0
\end{array}\right] F(1-F)^{-1} X_{t \mid t} .
$$

The corresponding $\mathrm{BN}$ cycle is

$$
c_{t}=y_{t}-\tau_{t}=-\left[\begin{array}{llll}
1 & 0 & 0 & 0
\end{array}\right] F(1-F)^{-1} X_{t \mid t} .
$$




\section{Appendix B. GMM Estimators}

To understand the potential biases caused by measurement errors, consider a cross-section single-equation model as follows:

$$
\begin{gathered}
y_{i}=z_{i} \alpha+\chi_{i} \beta+u_{i}, \\
x_{i}=\chi_{i}+\varepsilon_{i},
\end{gathered}
$$

where $y_{i}$ is the dependent variable, $z_{i}$ is the vector of perfectly measured explanatory variables, such as cash flow, $\chi_{i}$ is the unobserved marginal $Q$, and $x_{i}$ is the average $Q$, which proxies for $\chi_{i}$.

By substituting (B2) into (B1), we have $y_{i}=z_{i} \alpha+x_{i} \beta+v_{i}$, where $v_{i}=u_{i}-\varepsilon_{i} \beta$. The correlation between $x_{i}$ and $v_{i}$ causes the estimate of $\beta$ to be biased downward (attenuation bias). If there is a positive correlation between the mismeasured $Q$ and the well-measured regressor (cash flow), the attenuation bias causes the coefficient of the well-measured regressor to be biased upward. To derive the GMM estimates, Erickson and Whited $(2000,2002)$ first "partial out" the perfectly measured variables $\left(z_{i}\right)$ in $(\mathrm{B} 1)$ and $(\mathrm{B} 2)$ :

$$
\begin{array}{r}
y_{i}-z_{i} \mu_{y}=\eta_{i} \beta+u_{i}, \\
x_{i}-z_{i} \mu_{x}=\eta_{i}+\varepsilon_{i},
\end{array}
$$

where $\left(\mu_{y}, \mu_{x}, \mu_{\chi}\right)=E\left[\left(z_{i}^{\prime} z_{i}\right)\right]^{-1} E\left[\left(z_{i}^{\prime}\left(y_{i}, x_{i}, \chi_{i}\right)\right]\right.$ and $\eta_{i}=\chi_{i}-z_{i} \mu_{\chi}$. The GMM estimators are calculated using the moment equations of $y_{i}-z_{i} \mu_{y}$ and $x_{i}-z_{i} \mu_{x}$, which are functions of unknown $\beta$ and the moments of $\left(u_{i}, \varepsilon_{i}, \eta_{i}\right)$. There are three second-order moment equations:

$$
\begin{gathered}
E\left[\left(y_{i}-z_{i} \mu_{y}\right)^{2}\right]=\beta^{2} E\left(\eta_{i}^{2}\right)+E\left(u_{i}^{2}\right), \\
E\left[\left(y_{i}-z_{i} \mu_{y}\right)\left(x_{i}-z_{i} \mu_{x}\right)\right]=\beta E\left(\eta_{i}^{2}\right), \\
E\left[\left(x_{i}-z_{i} \mu_{x}\right)^{2}\right]=E\left(\eta_{i}^{2}\right)+E\left(\varepsilon_{i}^{2}\right) .
\end{gathered}
$$

The third-order product moment equations comprise two equations with two unknowns:

$$
\begin{gathered}
E\left[\left(y_{i}-z_{i} \mu_{y}\right)^{2}\left(x_{i}-z_{i} \mu_{x}\right)\right]=\beta^{2} E\left(\eta_{i}^{3}\right), \\
E\left[\left(y_{i}-z_{i} \mu_{y}\right)\left(x_{i}-z_{i} \mu_{x}\right)^{2}\right]=\beta E\left(\eta_{i}^{3}\right) .
\end{gathered}
$$

Thus, we can have $\beta=E\left[\left(y_{i}-z_{i} \mu_{y}\right)^{2}\left(x_{i}-z_{i} \mu_{x}\right)\right] / E\left[\left(y_{i}-z_{i} \mu_{y}\right)\left(x_{i}-z_{i} \mu_{x}\right)^{2}\right]$ if $\beta \neq 0$ and $E\left(\eta_{i}^{3}\right) \neq 0$. The condition $E\left(\eta_{i}^{3}\right)=0$ is called an identification test. The estimated GMM3 estimator, $\beta$, is exactly identified and its validity requires the rejection of the identification test. An overidentified equation system can be obtained by combining the above second-order and third-order moment equations together with additional fourth-order moment equations, which include only one additional new parameter, $E\left(\eta_{i}^{4}\right)$ :

$$
\begin{gathered}
E\left[\left(y_{i}-z_{i} \mu_{y}\right)^{3}\left(x_{i}-z_{i} \mu_{x}\right)\right]=\beta^{3} E\left(\eta_{i}^{4}\right)+3 E\left(\eta_{i}^{2}\right) E\left(u_{i}^{2}\right), \\
E\left[\left(y_{i}-z_{i} \mu_{y}\right)^{2}\left(x_{i}-z_{i} \mu_{x}\right)^{2}\right]=\beta^{2}\left[E\left(\eta_{i}^{4}\right)+E\left(\eta_{i}^{2}\right) E\left(u_{i}^{2}\right)\right]+E\left(u_{i}^{2}\right)\left[E\left(\eta_{i}^{2}\right)+E\left(\varepsilon_{i}^{2}\right)\right], \\
E\left[\left(y_{i}-z_{i} \mu_{y}\right)\left(x_{i}-z_{i} \mu_{x}\right)^{3}\right]=\beta\left[E\left(\eta_{i}^{4}\right)+3 E\left(\eta_{i}^{2}\right) E\left(\varepsilon_{i}^{2}\right)\right] .
\end{gathered}
$$

GMM4 can then be estimated by numerically minimizing a quadratic form of asymptotic variance. Similarly, we can have GMM5 estimates, which additionally utilize the equations for the fifth-order product moments and the third-order nonproduct moments. To examine the validity of both GMM4 and GMM5, overidentification tests should be performed because the number of moment equations involved is larger than that of unknown parameters. 


\section{Internet Appendix for}

"Cash Flow Sensitivities and the Allocation of Internal Cash Flow" 


\section{IA.1 The equivalence of SUR and OLS estimates when the regressors are identical across different equations}

This appendix derives that SUR (seemingly unrelated regressions) estimates are equivalent to equation-by-equation OLS estimates if the same set of explanatory variables is included in each equation of a system-of-equations framework.

Consider the following equations:

$$
\left[\begin{array}{c}
y_{1} \\
y_{2} \\
\cdot \\
\cdot \\
\cdot \\
\cdot \\
y_{M}
\end{array}\right]=\left[\begin{array}{cccccc}
X_{1} & 0 & \cdot & \cdot & \cdot & 0 \\
0 & X_{2} & 0 & \cdot & \cdot & 0 \\
\cdot & \cdot & \cdot & \cdot & \cdot & \cdot \\
\cdot & \cdot & \cdot & \cdot & \cdot & \cdot \\
\cdot & \cdot & \cdot & \cdot & \cdot & \cdot \\
\cdot & \cdot & \cdot & \cdot & \cdot & \cdot \\
0 & \cdot & \cdot & \cdot & 0 & X_{M}
\end{array}\right]\left[\begin{array}{c}
\beta_{1} \\
\beta_{2} \\
\cdot \\
\cdot \\
\cdot \\
\cdot \\
\beta_{M}
\end{array}\right]+\left[\begin{array}{c}
\varepsilon_{1} \\
\varepsilon_{2} \\
\cdot \\
\cdot \\
\cdot \\
\cdot \\
\varepsilon_{M}
\end{array}\right]=X \beta+\varepsilon
$$

$E\left(\varepsilon \varepsilon^{\prime}\right)=\Omega$, where $\Omega=\Sigma \otimes I_{T}$ and $\Sigma=\left[\sigma_{i j}\right], i, j=1,2, \ldots, M$. When the regressors are identical across different equations, SUR estimates $\tilde{\beta}$ (system of equations) and OLS estimates $\hat{\beta}$ are numerically equivalent and equally efficient.

\section{Proof:}

and

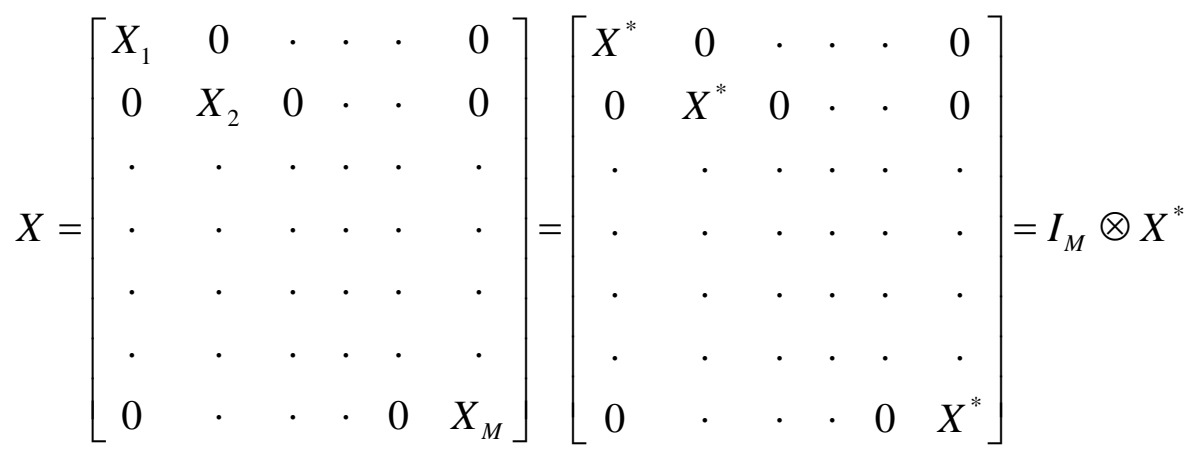

$$
\begin{aligned}
X^{\prime} \Omega^{-1} X & =\left(I_{M} \otimes X^{*}\right)^{\prime}\left(\Sigma \otimes I_{T}\right)^{-1}\left(I_{M} \otimes X^{*}\right) \\
& =\left(I_{M} \otimes X^{\prime *}\right)\left(\Sigma^{-1} \otimes I_{T}\right)\left(I_{M} \otimes X^{*}\right) \\
& =\left(\Sigma^{-1} \otimes X^{\prime *}\right)\left(I_{M} \otimes X^{*}\right) \\
& =\Sigma^{-1} \otimes\left(X^{\prime \prime} X^{*}\right)
\end{aligned}
$$




$$
\begin{aligned}
X^{\prime} \Omega^{-1} y & =\left(I_{M} \otimes X^{*}\right)^{\prime}\left(\Sigma \otimes I_{T}\right)^{-1} y \\
& =\left(I_{M} \otimes X^{\prime *}\right)\left(\Sigma^{-1} \otimes I_{T}\right) y \\
& =\left(\Sigma^{-1} \otimes X^{\prime *}\right) y
\end{aligned}
$$

The SUR estimator is therefore

$$
\begin{aligned}
& \tilde{\beta}=\left(X^{\prime} \Omega^{-1} X\right)^{-1} X^{\prime} \Omega^{-1} y \\
& =\left[\Sigma^{-1} \otimes\left(X^{\prime *} X^{*}\right)\right]^{-1}\left[\left(\Sigma^{-1} \otimes X^{\prime *}\right) y\right] \\
& =\left(\Sigma \otimes\left(X^{\prime *} X^{*}\right)^{-1}\right)\left(\Sigma^{-1} \otimes X^{\prime *}\right) y \\
& =\left(\Sigma \otimes\left(X^{\prime *} X^{*}\right)^{-1} X^{\prime *}\right) y \\
& =\left[\begin{array}{cccccc}
\left(X^{\prime *} X^{*}\right)^{-1} X^{\prime *} & 0 & \cdot & \cdot & \cdot & 0 \\
0 & \left(X^{\prime *} X^{*}\right)^{-1} X^{\prime *} & 0 & \cdot & . & 0 \\
\cdot & \cdot & \cdot & \cdot & \cdot & \cdot \\
\cdot & \cdot & \cdot & \cdot & \cdot & \cdot \\
\cdot & \cdot & \cdot & \cdot & \cdot & \cdot \\
\cdot & \cdot & \cdot & \cdot & \cdot & \cdot \\
0 & \cdot & \cdot & \cdot & 0 & \left(X^{\prime *} X^{*}\right)^{-1} X^{\prime *}
\end{array}\right]\left[\begin{array}{c}
y_{1} \\
y_{2} \\
\cdot \\
\cdot \\
\cdot \\
\cdot \\
y_{M}
\end{array}\right] \\
& =\left[\begin{array}{c}
\left(X^{\prime *} X^{*}\right)^{-1} X^{\prime *} y_{1} \\
\left(X^{\prime *} X^{*}\right)^{-1} X^{\prime *} y_{2} \\
\cdot \\
\cdot \\
\cdot \\
\cdot \\
\left(X^{\prime *} X^{*}\right)^{-1} X^{\prime *} y_{M}
\end{array}\right]=\left[\begin{array}{c}
\hat{\beta}_{1} \\
\hat{\beta}_{2} \\
\cdot \\
\cdot \\
\cdot \\
\hat{\beta}_{M}
\end{array}\right]=\hat{\beta}
\end{aligned}
$$

Note that this theorem holds regardless of the correlation among the disturbances across different equations.

\section{Reference}

Greene, W. H. 2012. Econometric Analysis. Seventh edition. Upper Saddle River: Prentice-Hall, Inc. 


\section{IA.2 Comparison with Gatchev, Pulvino, and Tarhan (2010; GPT hereafter)}

To reconcile our findings with GPT's, we reproduce their analysis using their cash flow identity as follows.

$$
\Delta \text { Cash }_{t}+\text { Div }_{t}+\text { CAPX }_{t}+\text { ACQUIS }_{t}-\text { ASALES }_{t}-(E Q I S S U-R P)_{t}-(\Delta L T D+\Delta S T D)_{t}=C F_{t} \text {, }
$$

where CAPX is net capital expenditures, ACQUIS is acquisitions, ASALES is sale of assets and investment, EQISSU stands for equity issuances, $R P$ represents equity repurchases, $\triangle L T D$ is net long-term debt issuances, and $\triangle S T D$ is net short-term debt issuances.

GPT's cash flow identity appears more detailed than our equation (1) because several variables in equation (1) consolidate some of the items in equation (GPT). ${ }^{1}$ Our purpose of consolidation is to simplify the empirical analysis and ease exposition. Untabulated robustness checks indicate that our results remain qualitatively the same if we use equation (GPT) instead of equation (1), so long as all items are defined properly using cash flow statements.

While the length of the cash flow identity is unimportant, the definitions of variables in the identity do matter. To ensure that equation (1) holds in the data for each firm each year, we rely solely on cash flow statements in defining variables. In contrast, GPT define variables in equation (GPT) using data from different sources. Specifically, they use balance sheet data to define $\Delta$ Cash, the change in net working capital, $\triangle S T D$, and $\triangle L T D$. They use income statement data to define cash flow, and rely on cash flow statement data to define equity issuances and repurchases, investment items, and cash dividends (Table III of GPT, page 737). As a result, their cash flow identity generally does not hold in the data. The disturbance to equality in equation (GPT) is further magnified by GPT's treatment of missing values in defining variables. GPT replace all missing values of the variables in equation (GPT) by zeros. ${ }^{2}$ This unusual treatment of missing values boosts their sample size to 237,412 firm-years, but increasingly worsens the cash flow inequality since not all components in equation (GPT) have missing values at the same time in a given firm-year.

We define variables in equation (GPT) by closely following GPT's definitions and their way of treating missing values. We end up with 221,119 firm-years, which are quite close to the size of their sample (237,412 firm-years). Table IA.2.1 reports the summary statistics of variables in equation (GPT) for this sample, which are comparable to those reported in Table IV of GPT. ${ }^{3}$ We also tabulate the statistics of $D I F^{G P T}$, which is defined as the difference between the left-hand and right-hand sides of equation (GPT), with all variables being deflated by the beginning-of-period total assets. The results reveal that, although the mean and median values of

\footnotetext{
${ }^{1}$ In particular, our measure of investment (Inv) aggregates capital expenditure (CAPX), acquisition (ACQUIS), and the sales of investment $(A S A L E S)$. Our measure of net debt issuance $(\triangle D)$ captures funds from both short-term $(\triangle S T D)$ and long-term debt $(\triangle L T D)$ financing. In addition, $\Delta E$ is equal to the difference between two items in equation (GPT), EQISSU and $R P$.

${ }^{2}$ For instance, without setting missing values to zero, their measure of cash flow can only be computed for roughly 124,406 firm-years for 1952-2007 in Compustat because of missing values in operating income, interest expenses, taxes, or the change in net working capital. In addition, GPT define a few variables, such as EQISSU and RP, over 1952-2007 using cash flow statement data. However, because Compustat cash flow statement data are only available from 1971 onwards, they set all missing values between 1952 and 1970 to zero. In footnote 9 of their paper, GPT suggest that their results are not qualitatively affected if they drop the observations with missing Compustat variables instead of setting them to zero. This is not surprising, however, given that the identity is still violated due to inconsistent definitions using data from different sources.

${ }^{3}$ The figures reported in IA.2.1 are not identical to those in GPT's Table IV due to the slight difference in sample size and the way of handling extreme observations (winsorization).
} 
$D I F^{G P T}$ are close to zero (0.013 and 0.001 , respectively), its distribution is widely dispersed, with a standard deviation equal to 0.396. Additional statistics (untabulated) indicate that the sample contains roughly $76 \%$ (25\%) of observations with the absolute value of $D I F^{G P T}$ larger than $1 \%$ (10\%) of total assets, confirming our conjecture that the cash flow identity (equation (GPT)) is severely violated in GPT’s data.

We then use this large sample to estimate the cash flow sensitivities of various uses of cash flows in equation (GPT). ${ }^{4}$ Consistent with GPT, we document drastic changes in the estimated coefficients of cash flow when we move from unconstrained single-equation models to constrained system-of-equations models. This result is untabulated but available upon request. To check whether the changes in coefficient estimates are caused by estimation methods or inconsistently defined variables, we re-estimate equations (2)-(6) simultaneously using the SUR method with constraints (7)-(9) imposed for our sample where cash flow identity holds generally. The results are reported in Panel A of Table IA.2.2.

Contrary to GPT, we find that the estimated coefficients $(\alpha, \beta$, and $\gamma), t$-statistics, and Rsquared values are almost identical to those reported in Panel A of Table $3 .^{5}$ This result is consistent with Greene (2012) who shows that SUR estimates are equivalent to equation-byequation OLS estimates if the same set of explanatory variables is included in each equation. More importantly, our findings suggest that it is the severely unbalanced cash flow identity in GPT's data that drives the significant differences in the estimated cash flow sensitivities between the unconstrained single-equation model and the constrained system-of-equations model.

GPT also argue that it is indispensable to take into account the intertemporal dependencies within and across various uses of cash flow when estimating cash flow sensitivities. For example, the current investment of a company may be affected by investment made last year, the change in cash holdings, and debt or equity issued last year. Without incorporating lagged dependent variables into equations (2)-(6), the estimation may suffer from model misspecification and omitted variable biases. Thus, to account for the interdependent nature of corporate policies, we augment equations (2)-(6) by adding lagged dependent variables (Inv $t-1$, $\Delta \operatorname{Cash}_{t-1}, \operatorname{Div}_{t-1}, \Delta D_{t-1}$, and $\left.\Delta E_{t-1}\right)$. We then estimate five equations both as unconstrained standalone equations using OLS and as constrained system-of-equations using SUR. ${ }^{6}$ Again, we find that the coefficients obtained using the two approaches are almost identical. We thus only report the results obtained using unconstrained standalone equations in Panel B of Table IA.2.2. This finding confirms our earlier inference that linear constraints are redundant if the cash flow identity holds in the data. Furthermore, we find that the inclusion of lagged dependent variables has no material impact on the coefficient estimates of cash flow. This result indicates that omitted variable biases associated with lagged dependent variables are almost negligible and far less significant than those proposed by GPT. Taken together, our analysis suggests that the importance of explicitly imposing adding-up constraints and adding lagged dependent variables is hugely exaggerated by GPT's reliance on a severely unbalanced cash flow identity in their data.

\footnotetext{
${ }^{4}$ In GPT's regression analysis (reported in their Tables V-X), all variables in equation (GPT) are unscaled. Instead, we follow the common practice by scaling the variables using total assets to mitigate the heterogeneity concerns.

${ }^{5}$ The estimated coefficients and $t$-statistics are very similar but not identical to those reported in Panel A of Table 3 because the cash flow identity (equation (1)) does not hold perfectly in our data. Thus, imposing the linear constraints (7)-(9) explicitly can still make a minor difference.

${ }^{6}$ Apart from constraints (7)-(9), we also impose five additional constraints that the coefficients of the five lagged (predetermined) dependent variables sum to zero across equations.
} 


\section{Table IA.2.1 Summary statistics of GPT's sample}

The sample contains the firms from Compustat for 1952-2007. The sampling process follows Gatchev, Pulvino, and Tarhan (2010). The variables are defined following GPT's Table III. DIF ${ }^{G P T}$ is the difference between the left-hand and right-hand sides of equation (GPT). Q1 and Q3, stand for the 25th and 75th percentiles of the distribution, respectively. All variables are deflated by the beginning-ofperiod total assets and winsorized at the top and bottom 1\% of their distributions.

\begin{tabular}{lccccccc}
\hline Variables & Mean & $\begin{array}{c}\text { Standard } \\
\text { Deviation }\end{array}$ & Minimum & Q1 & Median & Q3 & Maximum \\
\hline CAPX & 0.093 & 0.139 & 0 & 0.020 & 0.050 & 0.105 & 0.913 \\
ACQUIS & 0.024 & 0.092 & -0.004 & 0 & 0 & 0 & 0.698 \\
ASALES & 0.006 & 0.024 & 0 & 0 & 0 & 0.002 & 0.198 \\
$\Delta$ Cash & 0.069 & 0.382 & -0.457 & -0.023 & 0 & 0.041 & 2.636 \\
Div & 0.008 & 0.021 & 0 & 0 & 0 & 0.007 & 0.173 \\
$\Delta$ LTD & 0.033 & 0.183 & -0.442 & -0.015 & 0 & 0.034 & 1.104 \\
$\Delta$ STD & 0.012 & 0.124 & -0.445 & -0.007 & 0 & 0.018 & 0.725 \\
EQISSU & 0.182 & 0.711 & 0 & 0 & 0.001 & 0.020 & 5.461 \\
RP & 0.008 & 0.028 & 0 & 0 & 0 & 0 & 0.198 \\
CF & -0.045 & 0.473 & -3.269 & -0.039 & 0.052 & 0.126 & 0.585 \\
& & & & & & & \\
DIF GPT & 0.013 & 0.396 & -7.620 & -0.031 & 0.001 & 0.035 & 7.517 \\
\hline
\end{tabular}

\section{Reference}

Gatchev, V., T. Pulvino, and V. Tarhan. 2010. The interdependent and intertemporal nature of financial decisions: An application to cash flow sensitivities. Journal of Finance 65: 725-63. 


\section{Table IA.2.2 Estimating cash flow sensitivities with linear constraints and lagged dependent variables}

The data are from Compustat and CRSP for 1971-2011. The dependent variables are five uses of cash flow (CF), which include the change in cash holdings ( $\triangle$ Cash), investment (Inv), cash dividends (Div), net debt issued $(\Delta D)$, and net equity issued $(\Delta E)$. Ln(Assets) is the natural log of the total book value of assets. $M B$ is defined as the market value of assets divided by the book value of assets. Tangibility is the net PPE over total assets. Sales Growth is the change in net sales scaled by lagged net sales. Leverage is defined as total debt (the sum of short-term and longterm debt) divided by total assets. To estimate regressions with firm fixed effects in both panels, we demean the dependent and all independent variables in the equations. The constant term and year dummies are included in regressions but not reported. Coefficients significant at the $10 \%$, $5 \%$, and $1 \%$ levels are indicated by $*, * *$, and $* * *$, respectively. The $t$-statistics are presented in parentheses. Panel A reports the results obtained using SUR with constraints (7)-(9). Panel B estimates equations using OLS separately, without linear constraints.

\begin{tabular}{|c|c|c|c|c|c|c|c|c|c|c|}
\hline \multirow{3}{*}{$\begin{array}{l}\text { Dependent } \\
\text { Variables }\end{array}$} & \multicolumn{5}{|c|}{ Panel A: System of equations with linear constraints } & \multicolumn{5}{|c|}{ Panel B: Standalone equations without constraints } \\
\hline & (1) & (2) & (3) & (4) & (5) & $(6)$ & $(7)$ & $(8)$ & $(9)$ & $(10)$ \\
\hline & $\operatorname{Inv} v_{t}$ & $\Delta$ Cash $_{t}$ & $\operatorname{Div}_{t}$ & $\Delta D_{t}$ & $\Delta E_{t}$ & $\operatorname{Inv} v_{t}$ & $\Delta \operatorname{Cash}_{t}$ & $\operatorname{Div}_{t}$ & $\Delta D_{t}$ & $\Delta E_{t}$ \\
\hline$C F_{t}$ & $\begin{array}{c}0.28 * * * \\
(45.3)\end{array}$ & $\begin{array}{c}0.33 * * * \\
(69.9)\end{array}$ & $\begin{array}{c}0.01 * * * \\
(21.5)\end{array}$ & $\begin{array}{c}-0.28 * * * \\
(-55.2)\end{array}$ & $\begin{array}{c}-0.10 * * * \\
(-20.2)\end{array}$ & $\begin{array}{c}0.26 * * * \\
(42.7)\end{array}$ & $\begin{array}{c}0.33 * * * \\
(70.5)\end{array}$ & $\begin{array}{c}0.01 * * * \\
(18.6)\end{array}$ & $\begin{array}{c}-0.29 * * * \\
(-56.7)\end{array}$ & $\begin{array}{c}-0.10 * * * \\
(-20.0)\end{array}$ \\
\hline$M B_{t-1}$ & $\begin{array}{c}0.02 * * * \\
(31.6)\end{array}$ & $\begin{array}{c}0.01 * * * \\
(11.9)\end{array}$ & $\begin{array}{c}0.00 * * * \\
(18.0)\end{array}$ & $\begin{array}{c}0.01 * * * \\
(13.5)\end{array}$ & $\begin{array}{c}0.02 * * * \\
(37.2)\end{array}$ & $\begin{array}{c}0.02 * * * \\
(28.4)\end{array}$ & $\begin{array}{c}0.01 * * * \\
(18.1)\end{array}$ & $\begin{array}{c}0.00 * * * \\
(10.9)\end{array}$ & $\begin{array}{c}0.01 * * * \\
(12.6)\end{array}$ & $\begin{array}{c}0.02 * * * \\
(38.6)\end{array}$ \\
\hline Sale $G_{t-1}$ & $\begin{array}{c}0.03 * * * \\
(14.5)\end{array}$ & $\begin{array}{l}0.00 \\
(1.1)\end{array}$ & $\begin{array}{c}-0.00 * * * \\
(-5.8)\end{array}$ & $\begin{array}{c}0.02 * * * \\
(11.3)\end{array}$ & $\begin{array}{c}0.01 * * * \\
(6.7)\end{array}$ & $\begin{array}{c}0.02 * * * \\
(9.6)\end{array}$ & $\begin{array}{c}0.01 * * * \\
(6.3)\end{array}$ & $\begin{array}{c}-0.00 * * * \\
(-4.7)\end{array}$ & $\begin{array}{c}0.01 * * * \\
(9.1)\end{array}$ & $\begin{array}{c}0.01 * * * \\
(7.9)\end{array}$ \\
\hline $\operatorname{Ln}(\text { Assets })_{t-1}$ & $\begin{array}{c}-0.02 * * * \\
(-20.1)\end{array}$ & $\begin{array}{c}-0.01 * * * \\
(-17.7)\end{array}$ & $\begin{array}{c}0.00 * * * \\
(3.5)\end{array}$ & $\begin{array}{c}-0.01 * * * \\
(-8.1)\end{array}$ & $\begin{array}{c}-0.03 * * * \\
(-32.2)\end{array}$ & $\begin{array}{c}-0.02 * * * \\
(-21.7)\end{array}$ & $\begin{array}{c}-0.01 * * * \\
(-17.4)\end{array}$ & $\begin{array}{c}0.00 * * * \\
(2.6)\end{array}$ & $\begin{array}{c}-0.01^{* * * *} \\
(-9.4)\end{array}$ & $\begin{array}{c}-0.03 * * * \\
(-32.4)\end{array}$ \\
\hline Leverage $_{t-1}$ & $\begin{array}{c}-0.15 * * * \\
(-29.5)\end{array}$ & $\begin{array}{c}0.01^{* *} \\
(2.3)\end{array}$ & $\begin{array}{c}-0.02 * * * \\
(-40.7)\end{array}$ & $\begin{array}{c}-0.22 * * * \\
(-52.6)\end{array}$ & $\begin{array}{c}0.06 * * * \\
(14.6)\end{array}$ & $\begin{array}{c}-0.15^{* * *} \\
(-29.0)\end{array}$ & $\begin{array}{l}0.00 \\
(0.8)\end{array}$ & $\begin{array}{c}-0.01^{* * *} \\
(-31.9)\end{array}$ & $\begin{array}{c}-0.22 * * * \\
(-49.6)\end{array}$ & $\begin{array}{c}0.06 * * * \\
(12.5)\end{array}$ \\
\hline Tangibility $_{t-1}$ & $\begin{array}{c}0.04 * * * \\
(5.3)\end{array}$ & $\begin{array}{c}0.07 * * * \\
(13.4)\end{array}$ & $\begin{array}{c}0.00 * * * \\
(3.7)\end{array}$ & $\begin{array}{c}0.07 * * * \\
(11.9)\end{array}$ & $\begin{array}{c}0.04 * * * \\
(7.5)\end{array}$ & $\begin{array}{c}0.05 * * * \\
(7.4)\end{array}$ & $\begin{array}{c}0.05^{* * * *} \\
(8.5)\end{array}$ & $\begin{array}{c}0.00 * * * \\
(3.0)\end{array}$ & $\begin{array}{c}0.06 * * * \\
(10.5)\end{array}$ & $\begin{array}{c}0.04 * * * \\
(6.4)\end{array}$ \\
\hline $\operatorname{Inv} v_{t-1}$ & & & & & & $\begin{array}{c}0.07 * * * \\
(12.9)\end{array}$ & $\begin{array}{c}-0.02 * * * \\
(-3.8)\end{array}$ & $\begin{array}{c}0.00 * * * \\
(3.6)\end{array}$ & $\begin{array}{c}0.06 * * * \\
(13.5)\end{array}$ & $\begin{array}{l}-0.00 \\
(-1.1)\end{array}$ \\
\hline$\Delta$ Cash $_{t-1}$ & & & & & & $\begin{array}{c}0.13 * * * \\
(24.5)\end{array}$ & $\begin{array}{c}-0.14 * * * \\
(-35.9)\end{array}$ & $\begin{array}{c}0.00 * * * \\
(4.0)\end{array}$ & $\begin{array}{c}0.01^{* * *} \\
(2.6)\end{array}$ & $\begin{array}{c}-0.03 * * * \\
(-5.8)\end{array}$ \\
\hline $\operatorname{Div}_{t-1}$ & & & & & & $\begin{array}{l}-0.03 \\
(-0.8)\end{array}$ & $\begin{array}{c}-0.28 * * * \\
(-9.0)\end{array}$ & $\begin{array}{c}0.35^{* * *} \\
(134.0)\end{array}$ & $\begin{array}{c}0.15^{* * *} \\
(4.4)\end{array}$ & $\begin{array}{c}-0.11^{* * *} \\
(-3.1)\end{array}$ \\
\hline$\Delta D_{t-1}$ & & & & & & $\begin{array}{c}-0.02^{* * *} \\
(-3.1)\end{array}$ & $\begin{array}{l}0.01 \\
(1.5)\end{array}$ & $\begin{array}{c}-0.00 * * * \\
(-3.6)\end{array}$ & $\begin{array}{c}-0.03^{* * * *} \\
(-5.6)\end{array}$ & $\begin{array}{c}0.01 * * * \\
(2.9)\end{array}$ \\
\hline$\Delta E_{t-1}$ & & & & & & $\begin{array}{c}-0.06 * * * \\
(-14.3) \\
\end{array}$ & $\begin{array}{c}0.02 * * * \\
(6.9)\end{array}$ & $\begin{array}{c}-0.00 * * * \\
(-10.5) \\
\end{array}$ & $\begin{array}{c}-0.03 * * * \\
(-9.9)\end{array}$ & $\begin{array}{c}-0.01 * \\
(-1.8)\end{array}$ \\
\hline Obser & 46,991 & 46,991 & 46,991 & 46,991 & 46,991 & 46,991 & 46,991 & 46,991 & 46,991 & 46,991 \\
\hline R-squared & 0.13 & 0.11 & 0.07 & 0.13 & 0.07 & 0.14 & 0.15 & 0.33 & 0.13 & 0.08 \\
\hline
\end{tabular}




\section{IA.3 OLS and GMM coefficients for investment equation (within transformation)}

We transform the observations for each firm into deviations from firm-specific average (within transformation). Then, each year we estimate the investment equation and obtain coefficients (marked in bold) using the GMM3, GMM4, and GMM5. To aggregate yearly coefficient estimates, we use minimum distance method (Erickson and Whited (2012)) for GMM estimators. The numbers reported at the end of the Appendix are those can be found in the investment equation of the Panel A (within transformation form) in Table 6. The instances in which both identification and over-identification are satisfied are highlighted in grey. The test statistics for Identification tests and J tests are reported with their P-values. Standard errors are included in parentheses under the estimated parameters.

\begin{tabular}{|c|c|c|c|c|c|c|c|c|c|}
\hline \multirow[b]{2}{*}{ Year } & \multirow{2}{*}{$\begin{array}{c}\text { ID } \\
\text { Test }\end{array}$} & \multicolumn{2}{|c|}{ J Test } & \multicolumn{3}{|c|}{ Coefficients of $M B$} & \multicolumn{3}{|c|}{ Coefficients of $C F$} \\
\hline & & GMM4 & GMM5 & GMM3 & GMM4 & GMM5 & GMM3 & GMM4 & GMM5 \\
\hline 1972 & $\begin{array}{c}\mathbf{2 . 1 9} \\
(0.33)\end{array}$ & $\begin{array}{c}\mathbf{0 . 2 8} \\
(0.87)\end{array}$ & $\begin{array}{c}\mathbf{5 . 1 3} \\
(0.40)\end{array}$ & $\begin{array}{c}\mathbf{0 . 6 3} \\
(1.27)\end{array}$ & $\begin{array}{c}1.32 \\
(1.94)\end{array}$ & $\begin{array}{c}\mathbf{0 . 2 0} \\
(0.32)\end{array}$ & $\begin{array}{l}-1.80 \\
(4.73)\end{array}$ & $\begin{array}{l}-4.33 \\
(7.74)\end{array}$ & $\begin{array}{l}\mathbf{- 0 . 2 3} \\
(1.24)\end{array}$ \\
\hline 1973 & $\begin{array}{c}\mathbf{0 . 3 9} \\
(0.82)\end{array}$ & $\begin{array}{c}\mathbf{4 . 0 0} \\
(0.14)\end{array}$ & $\begin{array}{c}\mathbf{4 . 8 9} \\
(0.43)\end{array}$ & $\begin{array}{c}\mathbf{0 . 0 6} \\
(0.17)\end{array}$ & $\begin{array}{c}\mathbf{0 . 0 5} \\
(0.02)\end{array}$ & $\begin{array}{c}\mathbf{0 . 0 4} \\
(0.02)\end{array}$ & $\begin{array}{c}\mathbf{0 . 2 3} \\
(0.49)\end{array}$ & $\begin{array}{c}\mathbf{0 . 2 6} \\
(0.16)\end{array}$ & $\begin{array}{c}\mathbf{0 . 2 8} \\
(0.15)\end{array}$ \\
\hline 1974 & $\begin{array}{c}1.37 \\
(0.50)\end{array}$ & $\begin{array}{c}3.18 \\
(0.20)\end{array}$ & $\begin{array}{c}\mathbf{4 . 8 7} \\
(0.43)\end{array}$ & $\begin{array}{c}\mathbf{- 0 . 1 1} \\
(0.17)\end{array}$ & $\begin{array}{c}\mathbf{0 . 1 0} \\
(0.10)\end{array}$ & $\begin{array}{c}\mathbf{0 . 0 8} \\
(0.07)\end{array}$ & $\begin{array}{c}\mathbf{0 . 9 5} \\
(0.46)\end{array}$ & $\begin{array}{c}\mathbf{0 . 3 5} \\
(0.30)\end{array}$ & $\begin{array}{c}\mathbf{0 . 4 2} \\
(0.20)\end{array}$ \\
\hline 1975 & $\begin{array}{c}\mathbf{0 . 2 0} \\
(0.91)\end{array}$ & $\begin{array}{c}\mathbf{0 . 4 3} \\
(0.81)\end{array}$ & $\begin{array}{c}6.23 \\
(0.28)\end{array}$ & $\begin{array}{l}\mathbf{- 0 . 2 0} \\
(0.93)\end{array}$ & $\begin{array}{c}\mathbf{0 . 0 0} \\
(0.07)\end{array}$ & $\begin{array}{c}\mathbf{0 . 0 1} \\
(0.07)\end{array}$ & $\begin{array}{c}\mathbf{0 . 3 7} \\
(0.17)\end{array}$ & $\begin{array}{c}\mathbf{0 . 3 5} \\
(0.09)\end{array}$ & $\begin{array}{c}\mathbf{0 . 3 4} \\
(0.09)\end{array}$ \\
\hline 1976 & $\begin{array}{c}1.90 \\
(0.39)\end{array}$ & $\begin{array}{c}\mathbf{0 . 8 1} \\
(0.67)\end{array}$ & $\begin{array}{l}\mathbf{1 0 . 5 1} \\
(0.06)\end{array}$ & $\begin{array}{c}\mathbf{0 . 1 9} \\
(0.25)\end{array}$ & $\begin{array}{c}\mathbf{0 . 0 3} \\
(0.04)\end{array}$ & $\begin{array}{c}\mathbf{0 . 4 0} \\
(0.11)\end{array}$ & $\begin{array}{c}\mathbf{0 . 4 5} \\
(0.19)\end{array}$ & $\begin{array}{c}\mathbf{0 . 4 8} \\
(0.13)\end{array}$ & $\begin{array}{c}\mathbf{0 . 4 1} \\
(0.28)\end{array}$ \\
\hline 1977 & $\begin{array}{c}\mathbf{0 . 2 5} \\
(0.88)\end{array}$ & $\begin{array}{c}\mathbf{0 . 0 8} \\
(0.96)\end{array}$ & $\begin{array}{c}2.37 \\
(0.80)\end{array}$ & $\begin{array}{c}1.27 \\
(10.85)\end{array}$ & $\begin{array}{c}-3.02 \\
0.00\end{array}$ & $\begin{array}{l}\mathbf{- 0 . 0 8} \\
(0.07)\end{array}$ & $\begin{array}{c}\mathbf{- 1 . 0 2} \\
(13.34)\end{array}$ & $\begin{array}{c}\mathbf{4 . 2 8} \\
(1.47)\end{array}$ & $\begin{array}{c}\mathbf{0 . 6 5} \\
(0.11)\end{array}$ \\
\hline 1978 & $\begin{array}{c}7.31 \\
(0.03)\end{array}$ & $\begin{array}{c}1.48 \\
(0.48)\end{array}$ & $\begin{array}{l}10.20 \\
(0.07)\end{array}$ & $\begin{array}{c}\mathbf{0 . 0 7} \\
(0.02)\end{array}$ & $\begin{array}{c}\mathbf{0 . 8 4} \\
(0.73)\end{array}$ & $\begin{array}{c}\mathbf{0 . 0 6} \\
(0.01)\end{array}$ & $\begin{array}{c}\mathbf{0 . 4 9} \\
(0.10)\end{array}$ & $\begin{array}{c}\mathbf{0 . 1 8} \\
(0.43)\end{array}$ & $\begin{array}{c}\mathbf{0 . 5 0} \\
(0.11)\end{array}$ \\
\hline 1979 & $\begin{array}{c}2.95 \\
(0.23)\end{array}$ & $\begin{array}{c}1.34 \\
(0.51)\end{array}$ & $\begin{array}{c}4.73 \\
(0.45)\end{array}$ & $\begin{array}{c}-\mathbf{- 0 . 1 2} \\
(0.12)\end{array}$ & $\begin{array}{c}\mathbf{- 0 . 5 8} \\
(0.60)\end{array}$ & $\begin{array}{l}\mathbf{- 0 . 0 1} \\
(0.03)\end{array}$ & $\begin{array}{c}\mathbf{0 . 4 4} \\
(0.13)\end{array}$ & $\begin{array}{c}\mathbf{0 . 5 6} \\
(0.40)\end{array}$ & $\begin{array}{c}\mathbf{0 . 4 2} \\
(0.09)\end{array}$ \\
\hline 1980 & $\begin{array}{c}\mathbf{0 . 6 4} \\
(0.72)\end{array}$ & $\begin{array}{c}3.10 \\
(0.21)\end{array}$ & $\begin{array}{c}9.96 \\
(0.08)\end{array}$ & $\begin{array}{c}1.57 \\
(12.53)\end{array}$ & $\begin{array}{c}\mathbf{0 . 4 1} \\
(0.21)\end{array}$ & $\begin{array}{c}\mathbf{0 . 4 7} \\
(0.15)\end{array}$ & $\begin{array}{c}-\mathbf{0 . 7 2} \\
(8.79)\end{array}$ & $\begin{array}{c}\mathbf{0 . 1 0} \\
(0.36)\end{array}$ & $\begin{array}{c}\mathbf{0 . 0 6} \\
(0.34)\end{array}$ \\
\hline 1981 & $\begin{array}{c}\mathbf{5 . 8 1} \\
(0.05)\end{array}$ & $\begin{array}{c}1.28 \\
(0.53)\end{array}$ & $\begin{array}{c}6.57 \\
(0.25)\end{array}$ & $\begin{array}{c}\mathbf{- 0 . 2 2} \\
(0.27)\end{array}$ & $\begin{array}{l}-3.26 \\
0.00\end{array}$ & $\begin{array}{c}\mathbf{0 . 6 7} \\
(0.97)\end{array}$ & $\begin{array}{c}1.25 \\
(0.78)\end{array}$ & $\begin{array}{c}\mathbf{9 . 2 5} \\
(2.22)\end{array}$ & $\begin{array}{l}\mathbf{- 1 . 0 7} \\
(2.44)\end{array}$ \\
\hline 1982 & $\begin{array}{c}\mathbf{0 . 1 9} \\
(0.91)\end{array}$ & $\begin{array}{c}\mathbf{1 . 0 5} \\
(0.59)\end{array}$ & $\begin{array}{c}4.39 \\
(0.49)\end{array}$ & $\begin{array}{c}\mathbf{0 . 2 3} \\
(1.11)\end{array}$ & $\begin{array}{c}\mathbf{0 . 0 1} \\
(0.05)\end{array}$ & $\begin{array}{c}\mathbf{0 . 5 9} \\
(0.19)\end{array}$ & $\begin{array}{c}\mathbf{0 . 3 9} \\
(0.78)\end{array}$ & $\begin{array}{c}\mathbf{0 . 5 6} \\
(0.16)\end{array}$ & $\begin{array}{c}\mathbf{0 . 1 1} \\
(0.34)\end{array}$ \\
\hline 1983 & $\begin{array}{c}\mathbf{8 . 5 9} \\
(0.01)\end{array}$ & $\begin{array}{c}1.39 \\
(0.50)\end{array}$ & $\begin{array}{c}3.84 \\
(0.57)\end{array}$ & $\begin{array}{c}\mathbf{0 . 2 7} \\
(0.17)\end{array}$ & $\begin{array}{c}\mathbf{0 . 0 9} \\
(0.03)\end{array}$ & $\begin{array}{c}\mathbf{0 . 1 1} \\
(0.02)\end{array}$ & $\begin{array}{c}\mathbf{0 . 0 9} \\
(0.12)\end{array}$ & $\begin{array}{c}\mathbf{0 . 2 4} \\
(0.13)\end{array}$ & $\begin{array}{c}\mathbf{0 . 2 3} \\
(0.13)\end{array}$ \\
\hline 1984 & $\begin{array}{c}4.56 \\
(0.10)\end{array}$ & $\begin{array}{c}\mathbf{0 . 5 8} \\
(0.75)\end{array}$ & $\begin{array}{c}4.30 \\
(0.51)\end{array}$ & $\begin{array}{c}\mathbf{0 . 1 9} \\
(0.21)\end{array}$ & $\begin{array}{c}\mathbf{0 . 3 4} \\
(0.23)\end{array}$ & $\begin{array}{c}\mathbf{0 . 3 1} \\
(0.11)\end{array}$ & $\begin{array}{c}\mathbf{0 . 1 2} \\
(0.07)\end{array}$ & $\begin{array}{c}\mathbf{0 . 0 9} \\
(0.09)\end{array}$ & $\begin{array}{c}\mathbf{0 . 0 9} \\
(0.08)\end{array}$ \\
\hline 1985 & $\begin{array}{c}4.23 \\
(0.12)\end{array}$ & $\begin{array}{c}2.66 \\
(0.27)\end{array}$ & $\begin{array}{c}6.24 \\
(0.28)\end{array}$ & $\begin{array}{c}1.29 \\
(5.02)\end{array}$ & $\begin{array}{c}-2.16 \\
(6.37)\end{array}$ & $\begin{array}{c}\mathbf{0 . 7 7} \\
(0.51)\end{array}$ & $\begin{array}{c}\mathbf{- 0 . 1 3} \\
(1.18)\end{array}$ & $\begin{array}{c}\mathbf{0 . 6 5} \\
(1.51)\end{array}$ & $\begin{array}{c}\mathbf{- 0 . 0 1} \\
(0.18)\end{array}$ \\
\hline 1986 & $\begin{array}{c}\mathbf{8 . 4 8} \\
(0.01)\end{array}$ & $\begin{array}{c}3.92 \\
(0.14)\end{array}$ & $\begin{array}{c}7.07 \\
(0.22)\end{array}$ & $\begin{array}{c}\mathbf{0 . 5 6} \\
(0.45)\end{array}$ & $\begin{array}{l}6.43 \\
0.00\end{array}$ & $\begin{array}{c}1.44 \\
(0.96)\end{array}$ & $\begin{array}{c}\mathbf{0 . 1 2} \\
(0.14)\end{array}$ & $\begin{array}{c}\mathbf{- 0 . 7 1} \\
(1.42)\end{array}$ & $\begin{array}{c}\mathbf{0 . 0 0} \\
(0.34)\end{array}$ \\
\hline 1987 & $\begin{array}{c}2.26 \\
(0.32)\end{array}$ & $\begin{array}{c}\mathbf{0 . 0 6} \\
(0.97)\end{array}$ & $\begin{array}{c}4.57 \\
(0.47)\end{array}$ & $\begin{array}{c}\mathbf{0 . 0 8} \\
(0.10)\end{array}$ & $\begin{array}{c}\mathbf{0 . 0 6} \\
(0.04)\end{array}$ & $\begin{array}{c}\mathbf{0 . 1 0} \\
(0.03)\end{array}$ & $\begin{array}{c}\mathbf{0 . 2 4} \\
(0.05)\end{array}$ & $\begin{array}{c}\mathbf{0 . 2 4} \\
(0.05)\end{array}$ & $\begin{array}{c}0.25 \\
(0.06)\end{array}$ \\
\hline 1988 & $\begin{array}{c}1.72 \\
(0.42)\end{array}$ & $\begin{array}{c}1.63 \\
(0.44)\end{array}$ & $\begin{array}{c}6.21 \\
(0.29)\end{array}$ & $\begin{array}{c}\mathbf{0 . 8 9} \\
(3.98)\end{array}$ & $\begin{array}{c}\mathbf{0 . 0 5} \\
(0.02)\end{array}$ & $\begin{array}{c}\mathbf{0 . 0 6} \\
(0.04)\end{array}$ & $\begin{array}{c}\mathbf{- 0 . 3 2} \\
(2.49)\end{array}$ & $\begin{array}{c}\mathbf{0 . 2 1} \\
(0.04)\end{array}$ & $\begin{array}{c}\mathbf{0 . 2 1} \\
(0.05)\end{array}$ \\
\hline 1989 & $\begin{array}{c}\mathbf{0 . 1 5} \\
(0.93)\end{array}$ & $\begin{array}{c}\mathbf{0 . 8 3} \\
(0.66)\end{array}$ & $\begin{array}{c}2.46 \\
(0.78)\end{array}$ & $\begin{array}{c}\mathbf{0 . 1 2} \\
(0.53)\end{array}$ & $\begin{array}{c}\mathbf{0 . 0 9} \\
(0.05)\end{array}$ & $\begin{array}{c}\mathbf{1 . 2 9} \\
(1.41)\end{array}$ & $\begin{array}{c}\mathbf{0 . 2 8} \\
(0.13)\end{array}$ & $\begin{array}{c}\mathbf{0 . 2 9} \\
(0.04)\end{array}$ & $\begin{array}{c}\mathbf{0 . 0 3} \\
(0.42)\end{array}$ \\
\hline 1990 & $\begin{array}{c}\mathbf{0 . 6 8} \\
(0.71)\end{array}$ & $\begin{array}{c}1.63 \\
(0.44)\end{array}$ & $\begin{array}{c}4.86 \\
(0.43)\end{array}$ & $\begin{array}{c}\mathbf{0 . 0 9} \\
(0.11)\end{array}$ & $\begin{array}{c}\mathbf{0 . 0 6} \\
(0.02)\end{array}$ & $\begin{array}{c}\mathbf{0 . 0 6} \\
(0.02)\end{array}$ & $\begin{array}{c}\mathbf{0 . 2 7} \\
(0.04)\end{array}$ & $\begin{array}{c}\mathbf{0 . 2 7} \\
(0.04)\end{array}$ & $\begin{array}{c}0.27 \\
(0.04)\end{array}$ \\
\hline 1991 & 2.63 & 0.79 & 4.13 & 0.85 & 0.60 & 0.24 & 0.13 & 0.16 & 0.22 \\
\hline
\end{tabular}




\begin{tabular}{|c|c|c|c|c|c|c|c|c|c|}
\hline & $(0.27)$ & $(0.67)$ & (0.53) & $(1.01)$ & $(0.25)$ & $(0.23)$ & (0.29) & $(0.19)$ & $(0.09)$ \\
\hline 1992 & $\begin{array}{c}7.73 \\
(0.02)\end{array}$ & $\begin{array}{c}\mathbf{0 . 6 4} \\
(0.72)\end{array}$ & $\begin{array}{c}5.53 \\
(0.36)\end{array}$ & $\begin{array}{c}1.97 \\
(11.04)\end{array}$ & $\begin{array}{c}\mathbf{0 . 5 2} \\
(0.32)\end{array}$ & $\begin{array}{c}\mathbf{0 . 1 3} \\
(0.04)\end{array}$ & $\begin{array}{c}\mathbf{0 . 0 6} \\
(1.23)\end{array}$ & $\begin{array}{c}\mathbf{0 . 1 7} \\
(0.18)\end{array}$ & $\begin{array}{c}\mathbf{0 . 2 1} \\
(0.06)\end{array}$ \\
\hline 1993 & $\begin{array}{l}1.67 \\
(0.43)\end{array}$ & $\begin{array}{c}1.16 \\
(0.56)\end{array}$ & $\begin{array}{c}3.52 \\
(0.62)\end{array}$ & $\begin{array}{c}\mathbf{0 . 0 6} \\
(0.13)\end{array}$ & $\begin{array}{c}\mathbf{0 . 1 6} \\
(0.07)\end{array}$ & $\begin{array}{c}\mathbf{0 . 1 2} \\
(0.04)\end{array}$ & $\begin{array}{c}0.23 \\
(0.07)\end{array}$ & $\begin{array}{c}0.19 \\
(0.06)\end{array}$ & $\begin{array}{c}\mathbf{0 . 2 0} \\
(0.05)\end{array}$ \\
\hline 1994 & $\begin{array}{c}5.34 \\
(0.07)\end{array}$ & $\begin{array}{c}2.83 \\
(0.24)\end{array}$ & $\begin{array}{c}3.62 \\
(0.60)\end{array}$ & $\begin{array}{c}\mathbf{0 . 1 5} \\
(0.09)\end{array}$ & $\begin{array}{c}\mathbf{0 . 0 8} \\
(0.04)\end{array}$ & $\begin{array}{c}\mathbf{0 . 0 8} \\
(0.03)\end{array}$ & $\begin{array}{c}\mathbf{0 . 2 5} \\
(0.07)\end{array}$ & $\begin{array}{c}\mathbf{0 . 2 8} \\
(0.05)\end{array}$ & $\begin{array}{c}\mathbf{0 . 2 8} \\
(0.05)\end{array}$ \\
\hline 995 & $\begin{array}{c}1.69 \\
(0.43)\end{array}$ & $\begin{array}{c}2.84 \\
(0.24)\end{array}$ & $\begin{array}{c}4.41 \\
(0.49)\end{array}$ & $\begin{array}{c}\mathbf{0 . 2 4} \\
(0.13)\end{array}$ & $\begin{array}{c}\mathbf{0 . 0 8} \\
(0.06)\end{array}$ & $\begin{array}{c}\mathbf{0 . 0 9} \\
(0.02)\end{array}$ & $\begin{array}{c}\mathbf{0 . 1 2} \\
(0.11)\end{array}$ & $\begin{array}{c}\mathbf{0 . 2 3} \\
(0.05)\end{array}$ & $\begin{array}{c}\mathbf{0 . 2 2} \\
(0.05)\end{array}$ \\
\hline 1996 & $\begin{array}{c}7.58 \\
(0.02)\end{array}$ & $\begin{array}{c}2.75 \\
(0.25)\end{array}$ & $\begin{array}{c}5.93 \\
(0.31)\end{array}$ & $\begin{array}{c}\mathbf{0 . 3 4} \\
(0.08)\end{array}$ & $\begin{array}{c}\mathbf{0 . 2 8} \\
(0.05)\end{array}$ & $\begin{array}{c}\mathbf{0 . 2 9} \\
(0.05)\end{array}$ & $\begin{array}{c}\mathbf{0 . 1 1} \\
(0.13)\end{array}$ & $\begin{array}{c}\mathbf{0 . 1 5} \\
(0.11)\end{array}$ & $\begin{array}{c}\mathbf{0 . 1 4} \\
(0.11)\end{array}$ \\
\hline 1097 & $\begin{array}{l}1.63 \\
(0.44)\end{array}$ & $\begin{array}{c}1.45 \\
(0.49)\end{array}$ & $\begin{array}{c}3.71 \\
(0.59)\end{array}$ & $\begin{array}{c}\mathbf{0 . 3 5} \\
(0.13)\end{array}$ & $\begin{array}{c}\mathbf{0 . 2 5} \\
(0.03)\end{array}$ & $\begin{array}{c}\mathbf{0 . 0 5} \\
(0.05)\end{array}$ & $\begin{array}{c}\mathbf{0 . 3 2} \\
(0.12)\end{array}$ & $\begin{array}{c}\mathbf{0 . 3 3} \\
(0.09)\end{array}$ & $\begin{array}{c}\mathbf{0 . 3 4} \\
(0.05)\end{array}$ \\
\hline 998 & $\begin{array}{c}5.90 \\
(0.05)\end{array}$ & $\begin{array}{c}1.91 \\
(0.39)\end{array}$ & $\begin{array}{c}5.29 \\
(0.38)\end{array}$ & $\begin{array}{c}\mathbf{0 . 7 7} \\
(1.12)\end{array}$ & $\begin{array}{c}\mathbf{0 . 7 2} \\
(0.51)\end{array}$ & $\begin{array}{c}\mathbf{0 . 3 8} \\
(0.14)\end{array}$ & & & $\begin{array}{l}\mathbf{- 0 . 0 6} \\
(0.17)\end{array}$ \\
\hline 1999 & $\begin{array}{c}4.58 \\
(0.10)\end{array}$ & $\begin{array}{c}\mathbf{4 . 6 7} \\
(0.10)\end{array}$ & & & & $\begin{array}{c}\mathbf{0 . 2 0} \\
(0.03)\end{array}$ & & & $\begin{array}{c}\mathbf{0 . 1 7} \\
(0.08)\end{array}$ \\
\hline חמר & $\begin{array}{c}7.41 \\
(0.02)\end{array}$ & $\begin{array}{c}2.52 \\
(0.28)\end{array}$ & $\begin{array}{c}2.60 \\
(0.76)\end{array}$ & & & $\begin{array}{c}\mathbf{0 . 0 9} \\
(0.02)\end{array}$ & $\begin{array}{c}\mathbf{0 . 2 4} \\
(0.08)\end{array}$ & & $\begin{array}{c}\mathbf{0 . 2 7} \\
(0.06)\end{array}$ \\
\hline 001 & $\begin{array}{c}2.97 \\
(0.23)\end{array}$ & $\begin{array}{c}1.52 \\
(0.47)\end{array}$ & $\begin{array}{c}2.91 \\
(0.71)\end{array}$ & $\begin{array}{c}\mathbf{0 . 1 5} \\
(0.15)\end{array}$ & $\begin{array}{c}\mathbf{0 . 2 1} \\
(0.10)\end{array}$ & $\begin{array}{c}\mathbf{0 . 0 9} \\
(0.03)\end{array}$ & $\begin{array}{c}\mathbf{0 . 0 9} \\
(0.23)\end{array}$ & $\begin{array}{l}\mathbf{0 .} \\
(0 .\end{array}$ & $\begin{array}{c}\mathbf{0 . 2 0} \\
(0.06)\end{array}$ \\
\hline 2002 & $\begin{array}{c}6.27 \\
(0.04)\end{array}$ & $\begin{array}{c}1.09 \\
(0.58)\end{array}$ & $\begin{array}{c}5.82 \\
(0.32)\end{array}$ & $\begin{array}{c}\mathbf{- 8 9 . 8 5} \\
0.00\end{array}$ & $\begin{array}{c}\mathbf{0 . 4 2} \\
(0.24)\end{array}$ & $\begin{array}{c}\mathbf{0 . 1 3} \\
(0.05)\end{array}$ & $\begin{array}{c}\mathbf{5 2 . 7 4} \\
(27.22)\end{array}$ & $\begin{array}{c}\mathbf{0 . 0 7} \\
(0.21)\end{array}$ & $\begin{array}{c}\mathbf{0 . 2 4} \\
(0.06)\end{array}$ \\
\hline 2003 & $\begin{array}{c}2.27 \\
(0.32)\end{array}$ & $\begin{array}{c}\mathbf{0 . 2 9} \\
(0.86)\end{array}$ & $\begin{array}{c}\mathbf{0 . 9 6} \\
(0.97)\end{array}$ & & & & & & $\begin{array}{c}\mathbf{0 . 2 1} \\
(0.06)\end{array}$ \\
\hline 2004 & $\begin{array}{c}5.34 \\
(0.07)\end{array}$ & $\begin{array}{c}2.01 \\
(0.37)\end{array}$ & $\begin{array}{c}7.27 \\
(0.20)\end{array}$ & $\begin{array}{c}\mathbf{0 . 2 9} \\
(0.12)\end{array}$ & $\begin{array}{c}2.53 \\
(4.12)\end{array}$ & $\begin{array}{c}\mathbf{0 . 2 7} \\
(0.08)\end{array}$ & $\begin{array}{l}-\mathbf{0 . 1 8} \\
(0.23)\end{array}$ & $\begin{array}{l}-4 . \\
(7 .\end{array}$ & $\begin{array}{l}-\mathbf{0 . 1 4} \\
(0.17)\end{array}$ \\
\hline ר & $\begin{array}{c}3.18 \\
(0.20)\end{array}$ & $\begin{array}{c}1.71 \\
(0.43)\end{array}$ & $\begin{array}{c}3.64 \\
(0.60)\end{array}$ & $\begin{array}{c}\mathbf{0 . 2 4} \\
(0.12)\end{array}$ & $\begin{array}{c}\mathbf{0 . 1 6} \\
(0.03)\end{array}$ & $\begin{array}{c}\mathbf{0 . 1 4} \\
(0.01)\end{array}$ & $\begin{array}{c}\mathbf{- 0 . 0 1} \\
(0.21)\end{array}$ & $\begin{array}{c}\mathbf{0 . 1 0} \\
(0.10)\end{array}$ & $\begin{array}{c}\mathbf{0 . 1 3} \\
(0.08)\end{array}$ \\
\hline 00 & $\begin{array}{c}1.31 \\
(0.52)\end{array}$ & $\begin{array}{c}3.14 \\
(0.21)\end{array}$ & $\begin{array}{c}4.23 \\
(0.52)\end{array}$ & $\begin{array}{c}\mathbf{0 . 6 0} \\
(0.31)\end{array}$ & $\begin{array}{c}\mathbf{0 . 2 3} \\
(0.42)\end{array}$ & $\begin{array}{c}\mathbf{0 . 5 3} \\
(0.27)\end{array}$ & & $\begin{array}{r}\mathbf{0 .} \\
(0 .\end{array}$ & $\begin{array}{c}-\mathbf{0 . 3 6} \\
(0.42)\end{array}$ \\
\hline 2007 & $\begin{array}{c}1.28 \\
(0.53)\end{array}$ & $\begin{array}{c}\mathbf{0 . 2 0} \\
(0.91)\end{array}$ & $\begin{array}{c}3.00 \\
(0.70)\end{array}$ & $\begin{array}{l}-\mathbf{0 . 3 0} \\
(0.42)\end{array}$ & $\begin{array}{l}-\mathbf{0 . 5 4} \\
(0.32)\end{array}$ & $\begin{array}{c}\mathbf{0 . 1 8} \\
(0.09)\end{array}$ & $\begin{array}{c}\mathbf{0 . 5 4} \\
(0.44)\end{array}$ & $\begin{array}{c}\mathbf{0 . 7 9} \\
(0.38)\end{array}$ & $\begin{array}{c}\mathbf{0 . 0 4} \\
(0.12)\end{array}$ \\
\hline 2008 & $\begin{array}{c}6.32 \\
(0.04)\end{array}$ & $\begin{array}{c}\mathbf{0 . 9 4} \\
(0.62)\end{array}$ & $\begin{array}{c}5.35 \\
(0.38)\end{array}$ & $\begin{array}{c}-\mathbf{0 . 0 4} \\
(0.03)\end{array}$ & $\begin{array}{c}\mathbf{- 0 . 0 5} \\
(0.03)\end{array}$ & $\begin{array}{c}\mathbf{0 . 1 4} \\
(0.07)\end{array}$ & $\begin{array}{c}\mathbf{0 . 4 0} \\
(0.07)\end{array}$ & $\begin{array}{c}0.42 \\
(0.06)\end{array}$ & $\begin{array}{c}\mathbf{0 . 1 2} \\
(0.13)\end{array}$ \\
\hline 2009 & $\begin{array}{c}2.98 \\
(0.23)\end{array}$ & $\begin{array}{c}1.74 \\
(0.42)\end{array}$ & $\begin{array}{c}2.11 \\
(0.83)\end{array}$ & $\begin{array}{c}-\mathbf{0 . 6 2} \\
(1.04)\end{array}$ & $\begin{array}{c}\mathbf{0 . 2 2} \\
(0.07)\end{array}$ & $\begin{array}{c}\mathbf{0 . 2 3} \\
(0.08)\end{array}$ & $\begin{array}{c}\mathbf{0 . 8 0} \\
(0.86)\end{array}$ & $\begin{array}{c}\mathbf{0 . 1 4} \\
(0.08)\end{array}$ & $\begin{array}{c}\mathbf{0 . 1 3} \\
(0.09)\end{array}$ \\
\hline 2010 & $\begin{array}{c}\mathbf{0 . 9 6} \\
(0.62)\end{array}$ & $\begin{array}{c}3.45 \\
(0.18)\end{array}$ & $\begin{array}{c}\mathbf{4 . 6 4} \\
(0.46)\end{array}$ & $\begin{array}{c}\mathbf{0 . 0 7} \\
(0.23)\end{array}$ & $\begin{array}{l}-\mathbf{0 . 0 5} \\
(0.05)\end{array}$ & $\begin{array}{c}\mathbf{0 . 0 0} \\
(0.01)\end{array}$ & $\begin{array}{c}\mathbf{0 . 2 8} \\
(0.09)\end{array}$ & $\begin{array}{c}\mathbf{0 . 3 2} \\
(0.06)\end{array}$ & $\begin{array}{c}\mathbf{0 . 3 0} \\
(0.06)\end{array}$ \\
\hline 2011 & $\begin{array}{c}\mathbf{1 . 1 6} \\
(0.56)\end{array}$ & $\begin{array}{c}\mathbf{0 . 4 3} \\
(0.81)\end{array}$ & $\begin{array}{c}3.42 \\
(0.64)\end{array}$ & $\begin{array}{c}\mathbf{0 . 0 0} \\
(0.09)\end{array}$ & $\begin{array}{c}\mathbf{0 . 0 6} \\
(0.02)\end{array}$ & $\begin{array}{c}\mathbf{0 . 0 5} \\
(0.01)\end{array}$ & $\begin{array}{c}\mathbf{0 . 2 5} \\
(0.10)\end{array}$ & $\begin{array}{c}\mathbf{0 . 1 8} \\
(0.04)\end{array}$ & $\begin{array}{c}\mathbf{0 . 1 9} \\
(0.04)\end{array}$ \\
\hline \multicolumn{4}{|c|}{$\begin{array}{c}\text { Fama-MacBeth/Minimum distance } \\
\text { Standard errors }\end{array}$} & $\begin{array}{l}-\mathbf{8 8 . 3 1} \\
(0.00)\end{array}$ & $\begin{array}{l}-2.92 \\
(0.00)\end{array}$ & $\begin{array}{c}\mathbf{0 . 0 8} \\
(0.00)\end{array}$ & $\begin{array}{c}0.26 \\
(0.02)\end{array}$ & $\begin{array}{c}0.25 \\
(0.01)\end{array}$ & $\begin{array}{c}\mathbf{0 . 2 5} \\
(0.01)\end{array}$ \\
\hline
\end{tabular}

\section{Reference}

Erickson, T., and T. M. Whited. 2012. Treating measurement error in Tobin's q. Review of Financial Studies 25: 1286-329. 